\title{
THE DEVELOPMENT OF THE CONSECRATION RITE FOR ABBESSES AND ABBOTS IN CENTRAL MEDIEVAL ENGLAND
}

\author{
BY KATIE ANN-MARIE BUGYIS
}

This article identifies, details, and contextualizes three stages in the development of the consecration rites for abbesses and abbots in liturgical books produced for bishops in England from 900 to 1200. It shows how these rites, through the prayers recited, insignia bestowed, chants sung, and bodily gestures performed, sought to articulate and impress the normative ideals of monastic leadership on those who were elected to exercise it and how liturgists variously altered these rites in response to changing ecclesiastical pressures. Most significantly, for much of the late Anglo-Saxon period, the consecration rites for abbesses and abbots were the same, but, over the course of the late eleventh and twelfth centuries, the rites were split along gender lines with the dissemination, adoption, and adaptation of the ordines found in episcopal books affiliated with the tradition commonly identified by scholars as the Pontifical Romano-Germanique. In sharp contrast to their predecessors, the new rites envisioned dramatically different spiritual and temporal authorities for abbesses and abbots, clearly subordinating the former's office to the latter's by thoroughly feminizing its exemplary form. Yet, as close study of the material remains from communities of women religious during this period reveals, the consecration rite for abbesses was limited in its effect on how they actually fashioned and displayed their own authorities.

The liturgical ordines for the consecration of abbesses and abbots offer important repositories of evidence for how the medieval Western church sought to ritually articulate and impress the normative ideals for this office upon those who were elected to it. Though monastic rules and, later, customaries detailed many of the essential qualities and daily roles and responsibilities that an abbess or abbot was to embody, the consecration rite sacralized a vowed religious's transition from community member to leader. All the prayers recited, insignia bestowed, chants sung, and bodily gestures performed were to work in concert to inspire, even fashion, the newly elect into a leader worthy of shepherding the flock entrusted to her or his care.

The consecration of an abbess or abbot was customarily an episcopal rite, performed by a bishop either in his cathedral or at a monastery's church or oratory. ${ }^{1}$

1 Penitentials in the Theodoran tradition, however, did allow priests to consecrate abbesses. P. W. Finsterwalder, ed., Die Canones Theodori Cantuariensis und ihre Überlieferungsformen, Untersuchungen zu den Bußbüchern des 7., 8. und 9. Jahrhunderts 1 (Weimar, 1929), Capitula Dacheriana, 239, chap. 3; Canones Gregorii, 253, chap. 5; Canones

Traditio 71 (2016), 91-141

(C) Fordham University, 2016

doi:10.1017/tdo.2016.3 
Over the course of the Middle Ages, the rite underwent considerable transformation, evolving from a simple prayer of blessing to a complex ordo composed of multiple prayers, ritual actions, and chants. In many respects, this transformation coincided with the development of the liturgical books that primarily contained the noneucharistic rites performed by a bishop or pontiff. ${ }^{2}$ Prayers of consecration and blessing once found in separate libelli and rotuli, or incorporated into sacramentaries, were relocated to and further elaborated in the books produced for episcopal use, though monastic use cannot be ruled out in some instances. ${ }^{3}$

The principal sources for many of the texts and symbols incorporated into the consecration rite for abbesses and abbots were the words of scripture and the Benedictine Rule, but sometimes prayers and chants from other liturgical rites and feasts were creatively repurposed. In the early stages of the development of the rite, a favored site for textual borrowings was the prayers for the ordination of a bishop, likely because of the many correspondences between the spiritual and temporal authorities of episcopal and monastic leaders. But many of these borrowings were excised from later versions of certain prayers, thus delineating more clearly the authorities deemed to befit bishops, abbots, and abbesses.

Cottoniani, 271, chap. 4; Discipulus Umbrensium, 315, II.iii.4: "Presbyter potest abbatissam consecrare cum misse celebratione." For the histories of these penitentials, see Allen Frantzen, The Literature of Penance in Anglo-Saxon England (New Brunswick, NJ, 1983); Raymond Kottje, "Paenitentiale Theodori," in Handwörterbuch zur deutschen Rechtsgeschichte, 5 vols. (Berlin, 1984) 3: cols. 1413-16; T. Charles-Edwards, "The Penitential of Theodore and the Iudicia Theodori," in Archbishop Theodore: Commemorative Studies on His Life and Influence, ed. Michael Lapidge (Cambridge, 1995), 141-74; Roy Flechner, "The Making of the Canons of Theodore," Peritia 17-18 (2003-4): 121-43; and Rob Meens, Penance in Medieval Europe, 600-1200 (Cambridge, 2014), 89-95.

A debt of gratitude is owed to the members of the Issues in Medieval Liturgy Seminar of the North American Academy of Liturgy, especially to Margot Fassler, Peter Jeffery, and Anne Bagnall Yardley, as well as to Eric Bugyis and Helen Gittos, who offered invaluable feedback on earlier versions of this article. Any remaining errors or omissions are mine alone.

2 R. E. Reynolds, "Pontifical," in Dictionary of the Middle Ages, 13 vols. (New York, 1987), 10:30-31; idem, "Image and Text: The Liturgy of Clerical Ordination in Early Medieval Art," Gesta 22 (1983): 27-38. For a close codicological study of the historical development of early episcopal books, see Niels Rasmussen, Les pontificaux du haut Moyen Âge: Genèse du livre liturgique de l'évêque (Leuven, 1998); idem, "Unité et diversité des pontificaux latins aux VIIIe, IXe, et Xe siècles," in Liturgie et l'Église particulière et liturgie de l'Église universelle (Rome, 1976), 393-410.

3 The research of Henry Parkes troubles the universal ascription of such liturgical books to episcopal usage. He provides compelling evidence for the monastic use of an early eleventhcentury episcopal book at St. Alban's in Mainz; see The Making of Liturgy in the Ottonian Church: Books, Music and Ritual in Mainz, 950-1050 (Cambridge, 2015), pt. 4. See also Helen Gittos, "Researching the History of Rites," in Understanding Medieval Liturgy: Essays in Interpretation, ed. eadem and Sarah Hamilton (Aldershot, 2016), 13-37, at 35-36. 
Throughout much of the Western church, the consecration rites for abbesses and abbots were the same until the introduction of the ordines found in episcopal books affiliated with the tradition commonly identified by scholars as the Pontifical Romano-Germanique (PRG) in the late tenth or early eleventh century and their widespread transmission during the eleventh and twelfth centuries. ${ }^{4}$ Feminine grammatical endings were simply interlineated above or marginally supplied beside references to the consecrand in prayers and rubrics. But a complete bifurcation of the rite along gender lines occurred when episcopal books in the PRG tradition promulgated distinct ordines for the consecrations of abbesses and abbots. The subsequent popularity of these ordines ensured that this division in the rite proliferated, at least until the beginning of the thirteenth century.

My primary goal in what follows will be to trace the development of the consecration rite for abbesses and abbots from unity to separation. Episcopal books produced in or transmitted to England during the central Middle Ages, from roughly 900 to 1200 , will limit this study's scope, though select earlier Frankish sacramentaries will be examined first for the purposes of contextualization. Codicological and textual analyses of extant English episcopal books from this period reveal that there were three stages in the development of the rite. I will detail each stage in turn. My choice of a single geographical location was motivated by the

4 Notably, the Old Spanish Libri ordinum contain separate consecration rites for abbesses and abbots. Manuscripts preserving the Libri ordinum date to the tenth and eleventh centuries, but much of the material contained in them can be traced back to the sixth and seventh centuries. On the Libri ordinum, see J. M. Pinell, "Liturgia (Hispánica)," Diccionario de historia ecclesiástica de España, 5 vols. (Madrid, 1972) 2:1303-20; and José Janini, Manuscritos litúrgicos, vol. 1, Castilla y Navarra (Burgos, 1977), 8-29. For the consecration rites for abbesses and abbots in the Libri ordinum, see Marius Férotin, ed., Le Liber Ordinum en usage dans l'église Wisigothique et Mozarabe d'Espagne du cinquième au onzième siècle, Monumenta ecclesiae liturgica 5 (Paris, 1904), 66-68 and 57-61, respectively. The standard history of the composition and transmission of the PRG, as well as the standard edition of the text, has long been Cyrille Vogel and Reinhard Elze, eds., Le pontifical romano-germanique du dixième siècle, Studi e testi 226-27, 269 (Vatican City, 1963-72). See also Vogel, Medieval Liturgy: An Introduction to the Sources, trans. William Storey and Niels Rasmussen (Washington, DC, 1986), 230-39. Vogel, continuing the work of his predecessor, Michel Andrieu, located the PRG's creation to St. Alban's in Mainz ca. 950. He characterized the PRG's advent as a decisive break in the development of episcopal books, which was the result of a coordinated reforming effort at St. Alban's and proved to be highly influential on the production of episcopal books throughout Western Europe by the turn of the millennium. Vogel's account has been challenged, I think persuasively, by the research of Sarah Hamilton and Henry Parkes. Hamilton questions the "axiomatic" influence of the PRG's ordines on late tenth- and eleventh-century penitential practice; see The Practice of Penance, 900-1050 (Woodbridge, 2001), chap. 4. Henry Parkes, through careful study of the extant liturgical books from Ottonian Mainz, has effectively disproved Andrieu's and Vogel's geographical and temporal localization of the PRG's genesis and their claims to its widespread dominance before 1050; see "Questioning the Authority of Vogel and Elze's Pontifical Romano-Germanique," in Understanding Medieval Liturgy, 75-101; and idem, Making of Liturgy. 
increased awareness among scholars that medieval liturgical practices, in all their particularities and, sometimes, peculiarities, are comprehended most fully on a local level, especially during the time period under consideration here. ${ }^{5}$ As I will show, the forms of the consecration rite for abbesses and abbots in use before the end of the eleventh century differed markedly from one place to another.

The ordo for the consecration of abbesses and abbots has been the subject of more general studies, sometimes inclusive of both Eastern and Western practices, by liturgical and monastic historians, notably Jules Baudot, Pierre Salmon, Robert Somerville, Armand Vielleux, Urbanus Bomm, and Adrien Nocent. ${ }^{6}$ More recently, the consecration rite for abbesses has attracted the attention of scholars interested in tracking the history of women's ordination through the medieval period, such as Gary Macy and Mary Schaefer. ${ }^{7}$ Beyond Schaefer's close textual analysis of the ordines for a woman deacon, monastic abbess, and canonical abbess from the PRG tradition, the development of the consecration rite for abbesses has yet to be studied intensively within a fixed geographical locale and chronological period or comparatively with the rite for abbots. This is the aim of my study. The fundamental questions that I seek to answer are: How did the consecration rite for abbots and abbesses change over time? What historical circumstances prompted these changes? What normative ideals for the abbatial office did the rite articulate? How did the rite's prayers, insignia, chants, and ritual actions construct and impress the temporal and spiritual authorities of abbesses and abbots? How were these authorities constructed and impressed differently when the rite divided along gender lines? And what effect did the new ordo have on the ways in which abbesses of Benedictine monasteries in central medieval England materially fashioned and displayed their own authorities through objects such as conventual and personal seals, monumental sculptures, and burial goods?

5 This fits well with the recent collection of essays edited by Helen Gittos and Sarah Hamilton, Understanding Medieval Liturgy.

6 J. Baudot, "Bénédiction d'un abbé et d'une abbesse," in DACL, 15 vols. (Paris, 190753), 4:723-27; P. Salmon, Étude sur les insignes du pontife dans le rite romain (Rome, 1955); R. Somerville, "Ordinatio abbatis' in the Rule of St. Benedict," Revue bénédictine 77 (1967): 246-63; A. Vielleux, "La théologie de l'abbatiat cénobitque et ses implications liturgiques," Vie spirituelle: Supplément 86 (1968): 351-93; U. Bomm, "Der neue Ritus des Abtsund Äbtissenenweihe," Heiliger Dienst 27 (1973): 148-52; A. Nocent, "L'ordo benedicitonis abbatis et abbatissae," Rivista liturgica 60 (1973): 321-25; and idem, "Monastic Rites and Religious Profession," in The Church at Prayer: An Introduction to the Liturgy, vol. 3, The Sacraments, ed. Aimé Martimort, trans. Matthew O'Connell (Collegeville, MN, 1987), 285-310.

7 G. Macy, The Hidden History of Women's Ordination: Female Clergy in the Medieval West (Oxford, 2005); M. Schaefer, Women in Pastoral Office: The Story of Santa Prassede, Rome (Oxford, 2013). 


\section{Frankish Sacramentaries}

The earliest evidence for the consecration rite for an abbess or abbot in the Western church survives in ninth-century manuscripts of the Gregorian Sacramentary. ${ }^{8}$ It consists of only one prayer, "Concede quesumus omnipotens deus," and it is succinct in its request for the bestowal of God's gift of grace on the recently elected abbess or abbot. ${ }^{9}$ Given the widespread influence that the Gregorian Sacramentary came to exert over Western liturgical rites, this prayer would have an enduring afterlife, often appearing with only slight variation as the opening prayer in the collections of prayers that would constitute the consecration rite in later sacramentaries and episcopal books produced across the Continent and in England.

In eighth- and ninth-century Frankish sacramentaries, the consecration rite "tended to vary and become more complex," as Adrien Nocent has observed. ${ }^{10}$ The prayers found in the late eighth-century Gellone Sacramentary and the early ninth-century Phillipps Sacramentary illustrate well some of the early additions made to the rite. ${ }^{11}$ The collections of prayers in both sacramentaries are headed by two different rubrics. The first, "oratio ad abbatem faciendum," precedes the Gregorian prayer mentioned above, ${ }^{12}$ and the second, "oratio quando abbas vel abbatissa ordinatur in monasterio," precedes three prayers that appear to be alternate forms of blessing, as the second and third prayers are

8 It should be noted that the Gregorian Sacramentary chiefly contains materials from the seventh and eighth centuries, but the rite for the consecration of an abbot is not found in earlier Roman-rite sacramentaries. See Somerville, "Ordinatio abbatis," 257-59 and Nocent, "Monastic Rites," 301. For a helpful introduction to the history of and scholarship on the Gregorian Sacramentary, see Marcel Metzger, Les sacramentaires, Typologie des sources du Moyen Âge occidental 70 (Turnhout, 1994), 57-80.

9 "Concede quesumus omnipotens deus et famulum tuum ill. vel illam quem ad regimen animarum eligimus, gratie tue dono prosequere, ut te largiente, cum ipsa tibi nostra electione placeamus. Per." J. Deshusses, ed., Le sacramentaire Grégorien: Ses principales formes d'après les plus anciens manuscrits, Spicilegium Friburgense 16, 3rd ed. (Fribourg, 1992), 342, no. 996.

10 Nocent, "Monastic Rites," 301.

11 The Gellone Sacramentary, Paris, BN, MS lat. 12048, dates from roughly the last decade of the eighth century, and it was most likely copied at Holy Cross Abbey in Meaux, possibly for Cambrai Cathedral. It was in the possession of the Abbey of Gellone ca. 807. A. Dumas and J. Deshusses, eds., Liber sacramentorum Gellonensis, CCL 159, 159A (Turnhout, 1981). The Phillipps Sacramentary, Berlin, Staatsbibliothek, MS lat. 104 (olim Phillipps 1667), was produced ca. 800 in eastern Francia, near Trier. O. Heiming, ed., Liber sacramentorum Augustodinensis, CCL 159B (Turnhout, 1984). Both sacramentaries have been categorized as eighth-century Gelasians. A. Chavasse, "Le sacramentaire gélasien du VIIIe siècle: Ses deux principales formes," Ephemerides liturgicae 73 (1959): 249-98; idem, Le sacramentaire dans le groupe dit "Gélasiens du VIIIe siècle": Étude des procédés de confection et synoptiques nouveau modèle (Steenbrugge, 1984); Metzger, Les sacramentaires, 107-13.

12 Liber sacramentorum Gellonensis, 399, no. 2576; cf. Liber sacramentorum Augustodinensis, 193, no. 1591 . 
respectively headed by the rubrics, "item alia benedictio" and "item alia." The first prayer, "Cunctorum institutor deus qui per moysen" could be applied to either an abbot or an abbess, as the appropriate grammatical forms were supplied for both. It opened by recalling the Old Testament patriarch Moses's role in "governing the churches" that God had instituted. God was then asked to help the newly elect shepherd the flock entrusted to his/her care, so that at the end of his/her service, he/she might merit to hear the words spoken by the lord to the two enterprising servants in the parable of the talents: "Well done, good and faithful servant, since you have been faithful over a few things, you will be established over greater things. Enter into the joy of your lord" (Matt 25:21, 23; Luke 19:17). ${ }^{13}$ The prayer's opening association between Moses's and an abbot's/ abbess's governance would have recalled a similar comparison made near the beginning of one of the consecration prayers used for the ordination of a bishop found in the Gregorian, Gellone, and Phillipps Sacramentaries. ${ }^{14}$ This textual borrowing suggests a close kinship between the temporal and spiritual authorities envisioned for a bishop and an abbot/abbess. In the Gellone and Phillips Sacramentaries, this kinship would have been strengthened further in the consecration rite's third and final prayer through an allusion to the abbess's cathedra. As we will see, in later episcopal books, the prayers used for the bestowal of the pastoral staff and ring on an abbot/abbess also would have encouraged the affiliation of abbatial and episcopal authorities given their extensive borrowings from the prayers recited during the bestowal of the same insignia at a bishop's ordination. These ritual correspondences likely would not have been lost on those present at an abbot's/abbess's consecration, least of all on the presiding bishop, for he was to invest the elect with an authority made very much in his own image.

The second prayer, "Omnipotens sempiterne deus, affluentem illum spiritum," also contains feminine and masculine grammatical forms for its recipient, and, like the preceding prayer, the telos of its supplication was that the newly elect prove himself/herself worthy of everlasting rewards. To this end, the bishop

13 “Cunctorum institutor deus, qui per moysen famulum tuum ad gubernandas ecclesias prepositos instituisti, tibi supplices fundimus preces teque devotis mentibus exoramus ut hunc famulum tuum ill. quem conibentia et electio famularum/famulorum tuarum/tuorum abbatissam/abbatem hodie ovium tuorum esse instituit sic qui regat subditas/subditos commendatas/commendatos et cum illis omnibus regna celorum adepta/adeptus quatenus te opitulante domine apostolicis iugiter fulta/fultus doctrinis, centissimo cum fructus letus introeat portas paradisi atque te domine conlaudante audire mereatur: Euge euge famula/serve bona/ bone et fidelis, quia super pauca fuisti fidelis, supra multa te constituam, intra in gaudium domini tui. Quod ipse. Per dominum." Liber sacramentorum Gellonensis, 399, no. 2577. Cf. Liber sacramentorum Augustodinensis, 193, no. 1592.

14 "Deus honorum omnium, deus omnium dignitatum, que glorie tue sacratis famulantur ordinibus. Deus qui moysen famulum tuum secreti familiaris affectu..." Le sacramentaire Grégorien, 93, no. 23a. Cf. Liber sacramentorum Gellonensis, 393, no. 2549; Liber sacramentorum Augustodinensis, 189, no. 1566a. 
asked on the community's behalf that, with the pouring out of God's "overflowing spirit," the abbot/abbess be endowed with the following virtues: "perseverance in good work, constancy in adversity, tolerance in tribulations, desire in fasts, mercy in impieties, leadership in humilities, hatred in pride, love in faith, vigilance in teaching, continence in chastity, abstinence in luxuries, moderation in vagaries, [and] teaching in morals." For if he/she embodied these virtues, he/she would surely persevere in his/her ministry, "just as the Levite, holy Stephen, elected by the apostles, merited to endure." 15 The prayer's invocation of Stephen as a model for the abbatial office, like the previous prayer's appeal to Moses, is striking in its equal applicability across gender lines: both prayers called abbots and abbesses to lead their communities, by word and deed, in the exact same way, and, with the gracious assistance of the Spirit, they would be able to fulfill their ministries to the same fruitful effect. Also important to note is the prayer's reference to the elect's institution "per manus nostre impositionem." This reference suggests that the prayer was to be read by the bishop while he was laying hands on the consecrand. If this was the case, then the ritual action of the consecration of an abbot/abbess would have closely mirrored that of the ordination of a deacon, priest, or bishop: all received their orders by virtue of the bishop's laying on of hands. ${ }^{16}$

In "Domine deus omnipotens, qui sororem moysi mariam," the third and final prayer, the consecrand was scripted exclusively with feminine grammatical forms; thus, only Miriam, the sister of Moses, would serve as a type of the abbatial office for women religious. The prayer is resonant with evocative descriptions of communities of praise: "Miriam, coming through with the other women among the waves

15 “Omnipotens sempiterne deus, affluentem illum spiritum tuae benedictionis super famulam/famulum tuam/tuum ill. nobis orantibus propitiatus infunde, ut qui per manus nostre hodie inpositionem abbatissa/abbas instituetur sanctificatione tua dignitate electa/ electus permaneat, ut nunquam postmodum de tua gratia separetur indigna/indignus. Suscipiat te largiente hodie domine hi bono opere et perseverantiam, in adversis constantiam, in tribulationibus tolerantiam, in ieiuniis desiderium, in impietatibus misericordiam, in humilitatibus principatum, in superbia odium, in fide dilectionem, in doctrina pervigilantiam, in castitate continentiam, in luxuria abstinentiam, in varietatibus moderationem, in moribus doctrinam. Te munerante domine talis sanctus stephanus meruit perdurare. Tota ab odia diabolica conversatione dispitiat; te domine benedictionem largitatem contempnat presentiam, premia celestia desiderit sempiterna. Sit exemplum et forma iustitie ad gubernandam regendamque ecclesiam fideliter, ut speculatrix/speculator idonea/idoneus inter suos collegas semper efficiatur. Sit magni consilii, industrie censure, efficatie discipline. Ita te domine tribuente ut in omnibus mandatis tuis sine reprehensione tibi mundo corde deserviens, ad bravium superne vocationis multiplicati fenore cum centisimo fructu coronamque iustitiam et celestium thesaurorum donativa perveniat. Per dominum." Liber sacramentorum Gellonensis, 400, no. 2578. Cf. Liber sacramentorum Augustodinensis, 193-94, no. 1593.

16 The opening rubrics to the ordination rites for a deacon, priest, and bishop explicitly state that the bishop was to lay his hands on the ordinand. See Liber sacramentorum Gellonensis, 386, no. 2524; 388, no. 2529; and 392, no. 2544, respectively. 
of the sea, rejoicing with tympana and choirs" after the Israelites' miraculous escape from the Egyptians and the "angels, singing new songs" in eternal glory. These communities exemplified the harmonious concord, the "monastic norm," that the abbess was to uphold and inspire her sisters to achieve. Significantly, and unlike the previous two prayers, this one also includes a potent metonymy of female abbatial authority: the "maternal chair" in which the abbess was to be established "today." 17 This reference to the abbess's materna cathedra gives her authority a suggestively episcopal cast as it clearly borrows from one of the two possible consecratory prayers for the ordination of a bishop found in the Gellone and Phillipps Sacramentaries: "Lord, bestow on them [the bishops] the episcopal chair for ruling your church and your entire people."18 Arguably, the feminization of the abbess's cathedra would have asserted a significant distinction between her authority and a bishop's, yet in the other consecration prayers for an abbess, she was encouraged "to govern and rule the church" in much the same way that a bishop would have been: both were to pattern their governance on Moses's example. Though their seats of power oversaw different jurisdictions one a diocese, the other a monastery - both were essentially pastors, charged with leading their respective flocks to salvation.

Like the Gregorian Sacramentary's "Concede quesumus omnipotens deus," the three additional prayers found in the Gellone and Phillipps Sacramentaries were also incorporated into the various forms of the consecration rite that were composed and transmitted in sacramentaries and episcopal books produced across the Continent and in England from the tenth through the twelfth centuries. To comprehend better the incorporation of these prayers into episcopal books of English provenance, it is necessary to trace each stage in the development of the rite. As Table 1 shows, from the early tenth to the late twelfth century, the rite underwent three stages in development. In what follows, I will examine these stages in turn to show when and how the rite developed from a collection of prayers into a fully scripted ordo.

17 "Dominus deus omnipotens, qui sororem moysi mariam pereuntem ceteris mulieribus inter equoreas undas cum thymphanis et choris letam ad litus maris venire fecisti, te supplices deprecamur pro fideli famula ill. que hodie materna in cathedra universis subditis sibi abbatissa esse constituetur, ut ita a monastica norma tueatur cunctas famulas tuas quatenus eternam ad gloriam te auxiliante cum omnibus introeat leta ibique exultantes cum angelis, canentes cantica nova, sequantur agnum quocumque ierit prestantem domino nostro." Ibid., 400-401, no. 2579. Cf. Liber sacramentorum Augustodinensis, 194, no. 1594.

18 "Tribuas eis domine cathedram episcopalem ad regendam ecclesiam tuam et plebem universam." Liber sacramentorum Gellonensis, 395, no. 2550. Cf. Liber sacramentorum Augustodinensis, 190, no. $1566 \mathrm{e}$. 
Table 1: English episcopal books dating from the early tenth to the late twelfth centuries representing the stages in the development of the consecration rite for abbesses and abbots

\begin{tabular}{|c|c|c|c|c|c|c|c|c|c|c|}
\hline Name & Shelfmark & Date & Provenance & $\mathrm{M} / \mathrm{F}$ & $\begin{array}{l}\text { Same/ } \\
\text { Separate }\end{array}$ & Insignia & Interrogation & $\begin{array}{l}\text { Laying } \\
\text { Hands }\end{array}$ & $\begin{array}{l}\text { Enthro- } \\
\text { nement }\end{array}$ & $\overline{\text { Mass }}$ \\
\hline \multicolumn{11}{|l|}{ STAGE 1} \\
\hline Leofric Missal & $\begin{array}{l}\text { Bodl. Bodley } \\
\quad 579\end{array}$ & $\begin{array}{l}\text { s. } x^{\text {in }} \text {, with } \\
\text { addi- } \\
\text { tions } \\
\text { from } \\
\text { s. } x \text { and } \\
\text { s. } x i^{\text {med }}\end{array}$ & $\begin{array}{l}\text { Canterbury, then } \\
\text { Exeter by } \\
\text { s. xi }\end{array}$ & Both & Same & No & No & No & No & No \\
\hline $\begin{array}{l}\text { Dunstan } \\
\text { Pontifical }\end{array}$ & $\begin{array}{r}\text { Paris, } \mathrm{BN}, \\
\text { lat. } 943\end{array}$ & ca. 960 & $\begin{array}{l}\text { Canterbury, then } \\
\text { Sherborne by ca. } \\
993\end{array}$ & M & N/A & No & No & No & No & No \\
\hline $\begin{array}{l}\text { Ben. of Arch. } \\
\text { Robert }\end{array}$ & $\begin{array}{c}\text { Rouen, BM, } \\
369 \text { (Y.7) }\end{array}$ & $\begin{array}{c}\text { ca. } 980 \times \\
1020\end{array}$ & $\begin{array}{l}\text { New Minster, } \\
\text { Winchester }\end{array}$ & M & N/A & No & No & No & No & No \\
\hline $\begin{array}{l}\text { Egbert } \\
\text { Pontifical }\end{array}$ & $\begin{array}{l}\text { Paris, } \mathrm{BN}, \\
\text { lat. } 10575\end{array}$ & ca. 1000 & ?West Country & $2 \mathrm{M}, 1$ Both & Same & No & No & No & No & No \\
\hline $\begin{array}{l}\text { Lanalet } \\
\text { Pontifical }\end{array}$ & $\begin{array}{l}\text { Rouen, BM, } \\
368 \text { (A.27) }\end{array}$ & s. $x i^{\text {in }}$ & $\begin{array}{l}\text { Crediton; } \\
\text { St. Germans, } \\
\text { Cornwall; or } \\
\text { Wells }\end{array}$ & M & N/A & No & No & No & No & No \\
\hline \multicolumn{11}{|l|}{ STAGE 2} \\
\hline $\begin{array}{l}\text { Anderson } \\
\text { Pontifical }\end{array}$ & $\begin{array}{c}\text { BL, Add- } \\
\text { itional } \\
57337\end{array}$ & ca. 1000 & $\begin{array}{c}\text { Christ Church, } \\
\text { Canterbury }\end{array}$ & Some M/F & Same & $\begin{array}{l}\text { Staff and } \\
\text { ring }\end{array}$ & No & Yes & No & No \\
\hline
\end{tabular}


Table 1: Continued

\begin{tabular}{|c|c|c|c|c|c|c|c|c|c|c|}
\hline Name & Shelfmark & Date & Provenance & $\mathrm{M} / \mathrm{F}$ & $\begin{array}{l}\text { Same/ } \\
\text { Separate }\end{array}$ & Insignia & Interrogation & $\begin{array}{l}\text { Laying } \\
\text { Hands }\end{array}$ & $\begin{array}{l}\text { Enthro- } \\
\text { nement }\end{array}$ & Mass \\
\hline $\begin{array}{l}\text { Samson } \\
\text { Pontifical }\end{array}$ & CCCC 146 & s. $x i^{\text {in }}$ & $\begin{array}{l}\text { Winchester, then } \\
\text { Worcester by } \\
\text { s. xi/xii }\end{array}$ & Both & Same & $\begin{array}{l}\text { Staff and } \\
\text { ring }\end{array}$ & No & Yes & No & Yes \\
\hline \multirow[t]{3}{*}{$\begin{array}{c}\text { Claudius Pon- } \\
\text { tifical II }\end{array}$} & $\begin{array}{l}\text { BL, Cotton } \\
\text { Claudius } \\
\text { A.iii, fols. } \\
\text { 9-18, 87- } \\
105\end{array}$ & s. $x i^{2 / 4-m e d}$ & $\begin{array}{c}\text { Christ Church, } \\
\text { Canterbury }\end{array}$ & Both & Same & $\begin{array}{r}\text { Rule, staff, } \\
\text { and ring }\end{array}$ & No & Yes & No & Yes \\
\hline & CCCC 44 & s. $\mathrm{xi}^{2 / 4-3 / 4}$ & $\begin{array}{c}\text { Christ Church or } \\
\text { St. Augustine's, } \\
\text { Canterbury }\end{array}$ & Both & Same & $\begin{array}{r}\text { Rule, staff, } \\
\text { and ring }\end{array}$ & No & Yes & Yes & Yes \\
\hline & $\begin{array}{l}\text { Douai, BM, } \\
\quad 67\end{array}$ & s. $\mathrm{xii}^{1 / 2}$ & $\begin{array}{c}\text { Christ Church, } \\
\text { Canterbury }\end{array}$ & M & N/A & $\begin{array}{l}\text { Staff and } \\
\text { ring }\end{array}$ & No & Yes & No & No \\
\hline \multicolumn{11}{|l|}{ STAGE 3} \\
\hline & $\begin{array}{c}\text { BL, Cotton } \\
\text { Tiberius } \\
\text { C.i }\end{array}$ & $\begin{array}{l}\text { s. } \mathrm{xi}^{\text {med }} \text {, } \\
\text { with } \\
\text { addi- } \\
\text { tions } \\
\text { from } \\
\text { s. } \mathbf{x i}^{4 / 4}\end{array}$ & $\begin{array}{l}\text { Germany, then } \\
\text { Sherborne and } \\
\text { Salisbury by } \\
\text { s. } \mathbf{x i}^{4 / 4}\end{array}$ & Both & Separate & $\begin{array}{l}\text { M: rule and } \\
\text { staff; } F \text { : } \\
\text { rule }\end{array}$ & M & M & No & Yes \\
\hline $\begin{array}{l}\text { Anselm } \\
\text { Pontifical }\end{array}$ & $\begin{array}{l}\text { Dublin, } \\
\text { Trinity } \\
\text { College, } \\
98 \text { (B.3.6) }\end{array}$ & $\begin{array}{l}\text { s. } \mathrm{xi}^{\mathrm{ex}}, \\
\text { with } \\
\text { addi- } \\
\text { tions in } \\
\text { ca. } 1097 \\
\text { and ca. } \\
1120\end{array}$ & $\begin{array}{c}\text { Christ Church, } \\
\text { Canterbury }\end{array}$ & Both & Separate & $\begin{array}{l}\text { M: rule and } \\
\text { staff; } F \text { : } \\
\text { rule }\end{array}$ & M & M & No & Yes \\
\hline
\end{tabular}




\begin{tabular}{|c|c|c|c|c|c|c|c|c|c|c|}
\hline & $\begin{array}{l}\text { Cambridge, } \\
\text { Trinity } \\
\text { College, } \\
\text { B.11.10 }\end{array}$ & s. $\mathrm{xii}^{2 / 4}$ & $\begin{array}{c}\text { Christ Church, } \\
\text { Canterbury, } \\
\text { then Ely }\end{array}$ & Both & Separate & $\begin{array}{l}\text { M: rule and } \\
\text { staff; F: } \\
\text { rule }\end{array}$ & M & M & No & Yes \\
\hline \multirow[t]{5}{*}{$\begin{array}{l}\text { Magdalen } \\
\text { Pontifical }\end{array}$} & $\begin{array}{l}\text { Oxford, } \\
\quad \text { Magdalen } \\
\text { College, } \\
226\end{array}$ & s. $\mathrm{xii}^{2 / 4}$ & $\begin{array}{c}\text { Christ Church, } \\
\text { Canterbury }\end{array}$ & Both & Separate & $\begin{array}{l}\text { M: rule and } \\
\text { staff; F: } \\
\text { rule }\end{array}$ & M & M & No & Yes \\
\hline & CUL LI.2.10 & s. $\mathrm{xii}^{2 / 2}$ & $\begin{array}{c}\text { Diocese in province } \\
\text { of Canterbury, } \\
\text { likely Ely }\end{array}$ & $\begin{array}{l}\text { Both, but preface } \\
\text { only for M }\end{array}$ & Separate & $\begin{array}{l}\text { M: N/A; F: } \\
\quad \text { rule }\end{array}$ & N/A & N/A & N/A & Yes \\
\hline & $\begin{array}{l}\text { BL, Cotton } \\
\text { Vespasian } \\
\text { D.xv }\end{array}$ & ca. 1160 & $\begin{array}{l}\text { Canterbury, then } \\
\text { Exeter }\end{array}$ & M & N/A & $\begin{array}{l}\text { M: rule and } \\
\text { staff }\end{array}$ & M & M & No & Yes \\
\hline & $\begin{array}{l}\text { BL, Cotton } \\
\text { Tiberius } \\
\text { B.viii }\end{array}$ & s. $\mathrm{xii}^{3 / 4}$ & $\begin{array}{c}\text { Christ Church, } \\
\text { Canterbury }\end{array}$ & Both & Separate & $\begin{array}{l}\text { M: rule and } \\
\text { staff; F: } \\
\text { rule }\end{array}$ & M & M & No & Yes \\
\hline & CUL Ee.2.3 & s. $x_{i i}{ }^{e x}$ & $\begin{array}{l}\text { Province of } \\
\text { Canterbury }\end{array}$ & Both & Separate & $\begin{array}{l}\text { M: rule and } \\
\text { staff; F: } \\
\text { rule }\end{array}$ & M & M & No & Yes \\
\hline
\end{tabular}




\section{Stage-One English Episcopal Books}

The forms of the consecration rite attested in English episcopal books that date from the beginning of the tenth century to the beginning of the eleventh century are quite simple in comparison with those that the rite would assume in episcopal books dating to the eleventh and twelfth centuries. As Table 2 shows, they consist of only two to four prayers, and the first prayer is always the Gregorian "Concede quesumus omnipotens deus." In the Leofric Missal, only one other prayer follows: "Cunctorum institutor deus."19 In the so-called Benedictional of Archbishop Robert and the Egbert Pontifical, two different prayers succeed the first, and they do not appear in earlier sacramentaries. ${ }^{20}$ The first of the two additional prayers is "Deus qui sub tue maiestatis arbitrio," 21 and the second is "Super

19 Nicholas Orchard, ed., The Leofric Missal, HBS 113-14 (London, 2002), 2:424, nos. 2437, 2438. The Leofric Missal, Oxford, Bodleian Library, MS Bodley 579 (SC 2675), was probably first made for Plegmund, archbishop of Canterbury (890-914), in the early tenth century. Various additions of prayers, blessings, collects, chants, and masses were made to it over the course of the tenth century at Canterbury. It was in the possession of Leofric, bishop of Exeter (1050-72), by the middle of the eleventh century, at which time other texts were added. In the most recent edition of the manuscript, Nicholas Orchard has identified an updated Gelasian sacramentary-cum-pontifical at its core. The details of the manuscript's history prior to its arrival at Exeter have been much debated. For studies prior to Orchard's, see F. E. Warren, ed., The Leofric Missal (Oxford, 1983); Christopher Hohler, "Some Service-Books of the Later Saxon Church," in Tenth-Century Studies, ed. David Parsons (Chichester, 1975), 60-83, 217-27; David Dumville, Liturgy and the Ecclesiastical History of Late Anglo-Saxon England (Woodbridge, 1992), 82.

20 The so-called Benedictional of Archbishop Robert, Rouen, Bibliothèque municipale, MS 369 (Y.7), was produced at New Minster, Winchester ca. 980x1020, probably for Ethelgar, the reigning abbot (964-80), who later became the bishop of Selsey (980-90/92). Its name, the Benedictional of Archbishop Robert, derives from its one-time owner, who may have been Robert of Jumièges, archbishop of Canterbury (1051-52), or Robert, archbishop of Rouen (990-1037). Liturgical and art-historical evidence suggests a late tenth-century New Minster provenance, though David Dumville has advocated for a later dating based on paleographical evidence. For the consecration prayers for abbots, see H. A. Wilson, ed., The Benedictional of Archbishop Robert, HBS 24 (London, 1903), 130-31. The Egbert Pontifical, Paris, BN, MS lat. 10575, was produced ca. 1000, perhaps in the West Country. For the consecration prayers for abbesses and abbots, see H. M. J. Banting, ed., Two Anglo-Saxon Pontificals (The Egbert and Sidney Sussex Pontificals), HBS 104 (London, 1989), 114. Helen Gittos summarizes the historiography on the Benedictonal of Archbishop Robert and the Egbert Pontifical in Liturgy, Architecture, and Sacred Places in Anglo-Saxon England (Oxford, 2013), 44, $280-81$.

21 "Deus qui sub tue maiestatis arbitrio omnium regnorum contines potestates tibi supplices fundimus preces humiliter exorantes, ut hunc famulum tuum a nobis indignis in gradum abbatis electum superne tue summeque sanctificationis gratia benedicere digneris ut in diebus eius devotio renascatur discipline ut te adiuvante suis subditis tibi placita prebere possit exempla tibique cum timore subditus ac mansuetus militans tue maiestati mereatur ubique clypeo pacifice protegi. Dextera tue divinitatis eum digneris locupletari ut opem frugilem fratribus inferre et omnibus undique advenientibus pie possit profutura exhibere. Tu 
Table 2: The consecration prayers for an abbot or abbess found in stage-one English episcopal books

\begin{tabular}{|c|c|c|c|c|c|}
\hline Stage 1 & Leofric Missal & Dunstan Pontifical & Ben. of Arch. Robert & Egbert Pontifical & Lanalet Pontifical \\
\hline$\overline{\text { Date }}$ & $\begin{array}{l}\text { s. } \mathrm{x}^{\text {in }} \text {, with additions } \\
\text { from s. } \mathrm{x} \text { and s. } \mathrm{xi}^{\text {med }}\end{array}$ & ca. 960 & ca. $980 \times 1020$ & ca. 1000 & s. $x i^{\text {in }}$ \\
\hline $\begin{array}{l}\text { Opening } \\
\text { Rubric }\end{array}$ & $\begin{array}{l}\text { Oratio ad abbatem vel } \\
\text { abbatissam } \\
\text { faciendum }\end{array}$ & $\begin{array}{l}\text { Incipit benedictio } \\
\text { abbatis }\end{array}$ & $\begin{array}{l}\text { Incipit benedictio } \\
\text { abbatis }\end{array}$ & $\begin{array}{l}\text { Consecratio abbatis sive } \\
\text { abbatisse }\end{array}$ & Benedictio abbatis \\
\hline \multirow[t]{3}{*}{$\begin{array}{l}\text { Prayers } \\
\quad[\text { Gender }]\end{array}$} & $\begin{array}{l}\text { 1. Concede quesumus } \\
\text { omnipotens deus } \\
{[\mathrm{M} / \mathrm{F}]}\end{array}$ & $\begin{array}{l}\text { 1. Concede quesumus } \\
\text { omnipotens deus }[\mathrm{M}]\end{array}$ & $\begin{array}{l}\text { 1. Concede quesumus } \\
\text { omnipotens deus }[\mathrm{M}]\end{array}$ & $\begin{array}{l}\text { 1. Concede quesumus } \\
\text { omnipotens deus }[\mathrm{M}]\end{array}$ & $\begin{array}{l}\text { 1. Concede quesumus } \\
\text { omnipotens deus } \\
{[\mathrm{M}]}\end{array}$ \\
\hline & $\begin{array}{l}\text { 2. Deus institutor cunc- } \\
\text { torum qui per moysen } \\
{[\mathrm{M} / \mathrm{F}]}\end{array}$ & $\begin{array}{l}\text { 2. Deus consecrare ut } \\
\text { qui ubicumque totus } \\
\text { es }[\mathrm{M}]\end{array}$ & $\begin{array}{l}\text { 2. Deus qui sub tue } \\
\text { maiestatis arbitrio } \\
{[\mathrm{M}]}\end{array}$ & $\begin{array}{l}\text { 2. Deus qui sub tue } \\
\text { maiestatis arbitrio } \\
{[\mathrm{M} / \mathrm{F}]}\end{array}$ & $\begin{array}{l}\text { 2. Deus qui sub tue } \\
\text { maiestatis arbitrio } \\
{[\mathrm{M}]}\end{array}$ \\
\hline & & $\begin{array}{l}\text { 3. Deus qui sub tue } \\
\text { maiestatis arbitrio } \\
{[\mathrm{M}]}\end{array}$ & $\begin{array}{l}\text { 3. Super hunc famulum } \\
\text { tuum domine quesu- } \\
\text { mus }[\mathrm{M}]\end{array}$ & $\begin{array}{l}\text { 3. Super hunc famulum } \\
\text { tuum domine quesu- } \\
\text { mus }[\mathrm{M}]\end{array}$ & \\
\hline
\end{tabular}


hunc famulum tuum domine quesumus." 22 The opening relative clause to "Deus qui sub tue maiestatis arbitrio" borrows from a prayer with the same incipit that served as one of the collects to a mass said in time of war in the Old Gelasian Sacramentary. ${ }^{23}$ This textual borrowing seems to have inspired the martial imagery that dominates the first half of the prayer and culminates in the figuration of the abbot (and the abbess in the Egbert Pontifical) as a military leader, "battling for [God's] majesty," under the protection of "[God's] peace-giving shield." Such imagery may have gestured to the temporal dimension of an abbot's rule, possibly even to his military obligations as a feudal lord, but it would have highlighted the instrumental role that an abbot was to perform in battling for the salvation of souls. The abbot had to exercise his power fruitfully for the profit of all, not only to his fellow brothers in the monastery, but also to those seeking his care and counsel from outside the community.

In both the Egbert Pontifical and the Benedictional of Archbishop Robert, "Super hunc famulum tuum" beseeches God to grant the newly elect the gifts of "true knowledge, firm hope, right counsel, and holy teaching," but in the Benedictional a longer version of the prayer appears, which reminds the abbot of the pastoral burden with which the Benedictine Rule charged him: "He will return an account to our Lord Jesus Christ for all these [souls he rules]." ${ }^{24}$ The Lanalet Pontifical contains only the first two consecration prayers found in the Benedictional

illi esto honor, tu gaudium in domo, in itinere socius, in merore solatium, in ambiguitate consilium, in egritudine medicina, in laboribus adiutor, in adversis defensor, in tribulatione patientia. Ponat in te providentiam mentis per te discat consilio commissi sibi gregis gubernacula sapienter moderari. Ille semper felix semperque exultans de tue bonitatis ditatus beneficiis mereatur gaudere et prolixitatem presentis vite per tempora bona benigne suscipere ac supernis civibus angelorumque choris per eterna commercia copulari. Per." Two Anglo-Saxon Pontificals, 114. Cf. Benedictional of Archbishop Robert, 130-31.

22 "Super hunc famulum tuum domine quesumus dignanter intende, et da ei scientiam veram, spem firmam, consilium rectum, doctrinam sanctam ut aptus inveniatur ad accipiendam gratiam tue benedictionis. Per." The version of this prayer found in the Benedictional of Archbishop Robert contains additional lines following "tue benedictionis": "quatinus et ipse sine offensione sanctorum vestigia partum sequatur suosque sequaces sanctis ammonitionibus sequi faciat sciatque quia suscipit animas regendas. In die iudicii pro his omnibus rationem redditurus est domino nostro ihesu christo qui vivit et regnat per omnia." Two Anglo-Saxon Pontificals, 114. Benedictional of Archbishop Robert, 131.

23 "Deus, qui sub tue maiestatis arbitrio omnium regnorum contines potestatem, romani imperii propitiare principibus; ut qui tua expectant protectione defendi omnibus sint hostibus fortiores. Per." H. A. Wilson, ed., The Gelasian Sacramentary iii.lix (Oxford, 1894), 274. The so-called Old Gelasian Sacramentary, Vatican Library, Codex Vaticanus Reginensis latinus 316, was copied ca. 750 near Paris, at the community of women religious at Chelles. It is a Frankish recension of a Roman sacramentary. A. Chavasse, Le sacramentaire gélasien (Vaticanus Reginensis 316) sacramentaire presbytéral en usage dans les titres romains au VIIe siècle (Tournai, 1958); Metzger, Les sacramentaires (n. 8 above), 81-106.

24 "Sciatque abbas culpe pastoris incumbere quidquid in ovibus paterfamilias utilitatis minus potuerit invenire." Adalbert de Vogüé and Jean Neufville, eds., La Règle de Saint 
of Archbishop Robert, ${ }^{25}$ but all three appear in the Dunstan Pontifical, ${ }^{26}$ along with an additional prayer, "Deus consecrare ut qui ubicumque totus es." 27 This prayer more generally asks that God make his presence felt in the very prayers offered.

In all five of the Anglo-Saxon episcopal books discussed thus far, the consecration prayers were included under a simple rubric that only indicates what the prayers were to be used for - "ad abbatem vel abbatissam faciendam" (Leofric), "consecratio abbatis sive abbatisse" (Egbert), "benedictio abbatis" (Dunstan, Robert, and Lanalet) - not when, where, or how they were to be used. The further rubric of "alia" supplied before each prayer copied after "Concede quesumus omnipotens deus" suggests that these prayers were to serve as alternates to the first, selected at the presider's discretion. As the rubrics listed above indicate, only the prayers found in the Leofric Missal and Egbert Pontifical were clearly adaptable for the consecration of either an abbot or an abbess; both prayers in the Leofric Missal and one prayer in the Egbert Pontifical, "Deus qui sub tue maiestatis arbitrio," are grammatically gendered masculine in the

Benô̂t, SC 181-86 (Paris, 1971-77), 1:442. See also chap. 27.5-9 (ibid., 2:548-50), and cf. John 10:1-18; Matt. 18:11-14; Luke 15:3-7.

25 The Lanalet Pontifical, Rouen, Bibliothèque municipale, MS 368 (A.27), was produced in the beginning of the eleventh century, probably at Crediton; St. Germans, Cornwall; or Wells. These provenances are suggested by an Old English addition made to the manuscript, which states: "Bishop Lyfing owns this book." This Bishop Lyfing may have been either Lyfing, bishop of Cornwall and Crediton (1038-46), or Lyfing, bishop of Wells (ca. 9981013) and archbishop of Canterbury (1013-20). Victor Leroquais, G. H. Doble (the editor of the manuscript) and Nicholas Orchard have argued for either a Crediton or a St. Germans provenance, and David Dumville has supported a Wells provenance. See Leroquais, Les Pontificaux manuscrits des bibliothèques publiques de France, 4 vols. (Paris, 1937), 2:287-300; Doble, ed., Pontificale Lanaletense, HBS 74 (London, 1937); Orchard, The Sacramentary of Ratoldus, HBS 116 (Woodbridge, 2005), ciii; Dumville, "On the Dating of Some Late Anglo-Saxon Liturgical Manuscripts," Transactions of the Cambridge Bibliographical Society 10 (1991): 51-52; and idem, Liturgy, 86-87. For the consecration prayers for abbots, see Pontificale Lanaletense, 48.

26 Paris, BN, MS lat. 943 was produced ca. 960, very likely for Dunstan, archbishop of Canterbury (960-78). This manuscript has been described by Leroquais, Les pontificaux manuscrits, 2:6-10; Rasmussen, Les pontificaux (n. 2 above), 258-317. See also Jane Rosenthal, "The Pontifical of St Dunstan," in St. Dunstan: His Life, Times, and Cult, ed. Nigel Ramsay et al. (Woodbridge, 1992), 143-63; Dumville, Liturgy, 82-84; and Sarah Hamilton, "The Early Pontificals: The Anglo-Saxon Evidence Reconsidered from a Continental Perspective," in England and the Continent in the Tenth Century: Studies in Honour of Wilhelm Levison (1876-1947), ed. David Rollason et al. (Turnhout, 2010), 411-28, at 413. For a study and edition of this manuscript, see Marie Conn, "The Dunstan and Brodie (Anderson) Pontificals: An Edition and Study" (PhD diss., University of Notre Dame, 1993).

27 "Deus consecrare ut qui ubicumque totus es etiam hic adesse te in nostris precibus sentiamus et quicumque hic trine confessionis et sacre regenerationis effectum percipiunt. Gaudia eterna se adepturos sine fine letentur. Per dominum." "Dunstan and Brodie (Anderson) Pontificals," 134 . 
main text with feminine endings supplied interlinearly. Consideration of the intended oral performance of these consecration prayers helps to account for the infrequent appearance of ones explicitly scripted for a female recipient. The prayers that contain only masculine grammatical forms were likely to be feminized extemporaneously by the bishop during the celebration of an abbess's consecration.

\section{Stage-Two English Episcopal Books}

In the next stage in the development of the consecration rite, an actual ordo began to emerge, replete with rubrics that supplied directives for the sequence of prayers, the bestowal of insignia (Rule, staff, and/or ring), the singing of chants, and even the celebration of a mass following the consecration rite. Most of the episcopal books representative of this stage in development were produced in the early to mid-eleventh century and thus predate the transmission of the ordines belonging to the PRG tradition to England. Table 3 demonstrates that there is substantial overlap among the prayers that appear in these episcopal books with respect to both their texts and their sequence. Such overlap may be owed primarily to the fact that all of these books were produced at either Canterbury or Winchester, during a time when there was considerable exchange of personnel and manuscripts between the two sees. ${ }^{28}$ And yet, despite many similarities, no consecration ordo is exactly like another. Different arrangements, additional prayers, and changes to texts of prayers all contributed to making the ordo in each episcopal book a unique production.

\section{Anderson Pontifical}

As Table 3 shows, the ordo found in the Anderson Pontifical opens with the same prayer as the other four episcopal books: the Gregorian "Concede quesumus omnipotens deus." 29 This prayer is then followed by a sequence of four prayers: "Deus qui sub tue maiestatis arbitrio," "Cunctorum institutor deus qui per

28 This exchange was particularly dynamic when Elfheah, bishop of Winchester (9841006), became archbishop of Canterbury (1006-12) and when Stigand held the sees of Winchester and Canterbury in plurality (1052-70). See esp. A. Rumble, "From Winchester to Canterbury: Elfheah and Stigand; Bishops, Archbishops and Victims," in Leaders of the Anglo-Saxon Church: From Bede to Stigand, ed. idem (Woodbridge, 2012), 165-82, at 180-82.

29 The Anderson Pontifical, London, BL, MS Add. 57337, was produced ca. 1000 at Christ Church, Canterbury. For the dating and provenance of this manuscript, see Dumville, Liturgy, 77; idem, English Caroline Script and Monastic History: Studies in Benedictinism A.D. 950-1030 (Woodbridge, 1993), 106; and Janet Nelson and Richard Pfaff, "Pontificals and Benedictionals," in The Liturgical Books of Anglo-Saxon England, ed. R. Pfaff (Kalamazoo, MI, 1995), 87-98, at 91-92. For an edition of this manuscript, see Conn, "Dunstan and Brodie (Anderson) Pontificals." 
Table 3: The prayers, chants, and ritual actions comprising the ordo for the consecration of an abbot or abbess found in stage-two English episcopal books

\begin{tabular}{|c|c|c|c|c|c|}
\hline Stage 2 & Anderson Pontifical & Samson Pontifical & Claudius II Pontifical & CCCC 44 & Douai Pontifical \\
\hline Date & ca. 1000 & s. $x i^{\text {in }}$ & s. $x^{2 / 4-m e d}$ & s. $\mathrm{xi}^{2 / 4-3 / 4}$ & s. $x_{i i}^{1 / 2}$ \\
\hline Opening Rubric & $\begin{array}{l}\text { Incipiunt orationes de } \\
\text { ordinatione abbatis }\end{array}$ & $\begin{array}{l}\text { Benedictio ad ordi- } \\
\text { nandum abbatem }\end{array}$ & $\begin{array}{l}\text { Incipit consecratio } \\
\text { abbatis }\end{array}$ & $\begin{array}{l}\text { Incipit consecratio } \\
\text { abbatis }\end{array}$ & $\begin{array}{l}\text { Incipit consecratio } \\
\text { abbatis }\end{array}$ \\
\hline \multirow[t]{4}{*}{$\begin{array}{l}\text { Prayers, } \\
\text { Chants, and } \\
\text { Ritual } \\
\text { Actions } \\
\text { [Gender] }\end{array}$} & $\begin{array}{l}\text { 1. Concede quesumus } \\
\text { omnipotens deus } \\
{[\mathrm{M}]}\end{array}$ & $\begin{array}{c}\text { Ant. Exurgat deus ad } \\
\text { nostri famulatus }\end{array}$ & $\begin{array}{l}\text { 1. Concede quesumus } \\
\text { omnipotens deus } \\
{[\mathrm{M} / \mathrm{F}]} \\
\text { (Bestowal of Rule) }\end{array}$ & $\begin{array}{l}\text { 1. Concede quesumus } \\
\text { omnipotens deus } \\
{[\mathrm{M}]} \\
\text { (Bestowal of Rule) }\end{array}$ & $\begin{array}{l}\text { 1. Concede quesumus } \\
\text { omnipotens deus } \\
{[\mathrm{M}]}\end{array}$ \\
\hline & $\begin{array}{l}\text { 2. Deus qui sub tue } \\
\text { maiestatis arbitrio } \\
{[\mathrm{M}]}\end{array}$ & $\begin{array}{l}\text { 1. Concede quesumus } \\
\text { omnipotens deus } \\
{[\mathrm{M} / \mathrm{F}]}\end{array}$ & $\begin{array}{l}\text { 2. Accipe regulam a } \\
\text { sancto benedicto } \\
\text { abbate }[\mathrm{N}]\end{array}$ & $\begin{array}{l}\text { 2. Accipe regulam a } \\
\text { sancto benedicto } \\
\text { abbate }[\mathrm{N}]\end{array}$ & $\begin{array}{l}\text { 2. Deus qui sub tue } \\
\text { maiestatis arbitrio } \\
{[\mathrm{M}]}\end{array}$ \\
\hline & (Bestowal of Staff) & & $\begin{array}{l}\text { Ant. Sancte bene- } \\
\text { dicte confessor }\end{array}$ & $\begin{array}{l}\text { Resp. Sancte bene- } \\
\text { dicte confessor }\end{array}$ & \\
\hline & $\begin{array}{l}\text { 3. Accipe baculum } \\
\text { pastoralis officii et } \\
\text { monastici regiminis } \\
{[\mathrm{N}]}\end{array}$ & $\begin{array}{l}\text { 2. Deus qui sub tue } \\
\text { maiestatis arbitrio } \\
{[\mathrm{M} / \mathrm{F}]}\end{array}$ & $\begin{array}{l}\text { 3. Deus qui sub tue } \\
\text { maiestatis arbitrio } \\
{[\mathrm{M} / \mathrm{F}]}\end{array}$ & $\begin{array}{l}\text { 3. Omnipotens piis- } \\
\text { sime et misericor- } \\
\text { dissime domine } \\
{[\mathrm{M} / \mathrm{F}]}\end{array}$ & $\begin{array}{l}\text { 3. Super hunc } \\
\text { famulum tuum } \\
\text { domine quesumus } \\
{[\mathrm{M}]}\end{array}$ \\
\hline
\end{tabular}


Table 3: Continued

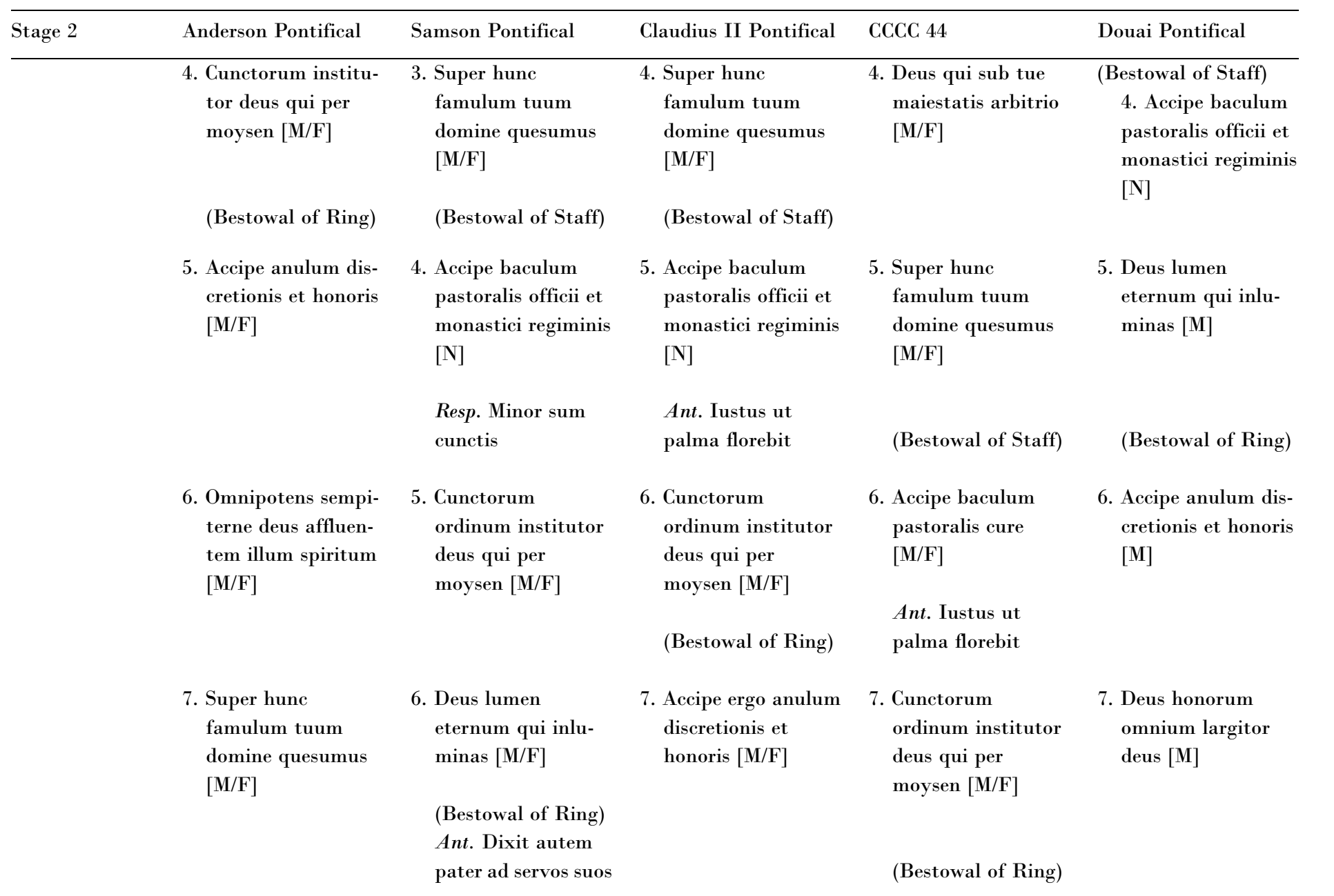


8. Domine deus omnipotens exaudi

preces nostras [M]

9. Respice domine super hunc

famulum tuum [M]
7. Accipe anulum discretionis et honoris [M/F $]$

Ant. Dedit pater penitenti filio

8. Omnipotens sempiterne deus affluentem $[M / F]$

Ant. Beati eritis

10. Omnipotens

clementissime pater tuam omnipotentiam $[\mathrm{M} / \mathrm{F}]$

11. Aspiciat et benedicat te dominus rector eternus [N]

\section{Benedicat te deus conditor celi et terre $[\mathrm{M} / \mathrm{F}]$}

10. Omnipotens sempiterne deus tuam omnipotentiam
8. Deus honorum omnium largitor $\operatorname{deus}[\mathbf{M} / \mathbf{F}]$

Ant. Dedit pater penitenti filio

9. Omnipotens sempiterne deus affluentem $[\mathrm{M} / \mathrm{F}]$ supplices depreca$\operatorname{mur}[\mathrm{M} / \mathrm{F}]$

11. Benedicat te deus [M/F]
8. Accipe ergo anulum discretionis et honoris $[\mathrm{M} / \mathrm{F}]$

8. Benedicat te deus conditor celi et terre [M]

Ant. Dedit pater penitenti filio

9. Omnipotens sempiterne deus affluentem $[\mathrm{M} / \mathrm{F}]$

\section{(Enthronement)}

Ant. Redemptor mundi

\section{Omnipotens clementissime pater tuam omnipoten- tiam $[\mathrm{M} / \mathrm{F}]$} conditor celi et terre 
Table 3: Continued

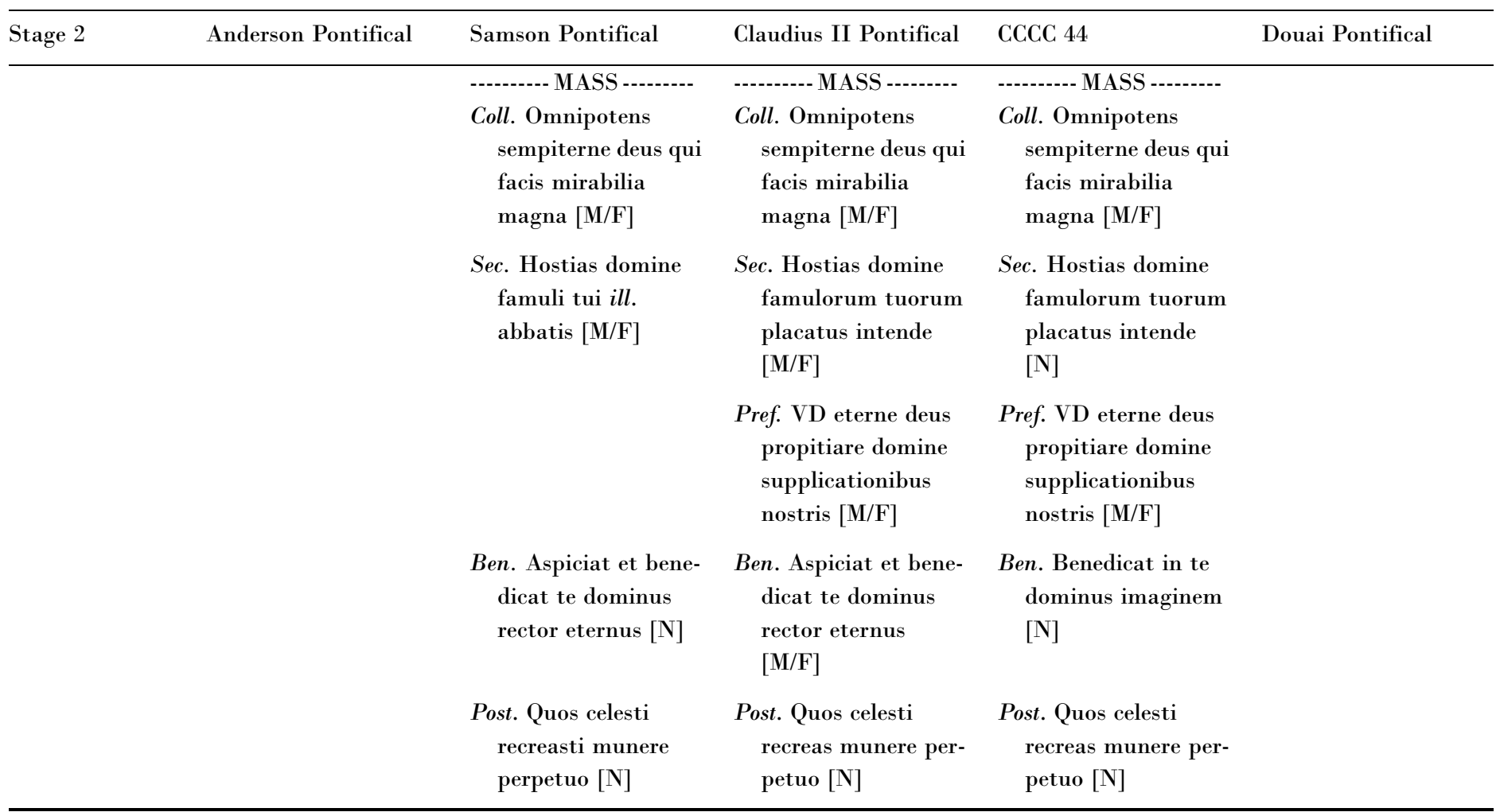


moysen," "Omnipotens sempiterne deus, affluentem illum spiritum," and "Super hunc famulum tuum domine quesumus." The texts of these prayers correspond closely with those found in the sacramentaries and episcopal books examined above. In the marginal space next to the second and third prayers, additional directives and prayers were supplied for the bestowal of the pastoral staff and ring. Beside "Cunctorum institutor deus," the scribe added a rubric directing the bishop to give the staff to the abbot as well as to recite the prayer, "Accipe baculum pastoralis officii et monastici regiminis," which commands the abbot to receive the "sign of holy governance" to good effect so that he "solidify the weak, strengthen the faltering, correct the crooked, and direct the upright on the way of eternal salvation." ${ }^{30}$ Directions for the bestowal of the ring as well as the accompanying prayer "Accipe anulum discretionis et honoris" appear next to "Omnipotens sempiterne deus." "31

Significantly, the prayers to be recited by the bishop during the bestowal of both the staff and ring reiterate, nearly verbatim, the prayers to be offered during the conferral of the same insignia on a bishop at his ordination. The prayer over the abbatial staff is a combination of two alternate prayers that could be used over an episcopal staff, excepting the clause relating the "power of building up the worthy and correcting the unworthy." 32 The prayer over the abbatial ring was similarly faithful in copying its episcopal exemplar; it lacks

30 "Hic detur baculus et dicat episcopus abbati. Accipe baculum pastoralis officii et monastici regiminis, et sis in corrigendis vitiis seviens in ira iudicium sine ira tenens cum iratus fueris misericordiam reminiscens. Accipe inquam baculum sacri moderaminis signum ut inbecilles consolides titubantes confirmes pravos corrigas rectos dirigas in via salutis eterne. Presente domino nostro ihesu christo qui cum patre et spiritu sancto vivit et regnat deus." Ibid., 315-16n824.

31 "Hic detur anulus abbati et dicatur ei. Accipe anulum discretionis et honoris integre fidei signaculum ut que signanda sunt signes et que aperienda sunt prodas et ut credentibus per fidem baptismatis divine misericordie viscera pandas, lapsis autem et penitentibus per ministerium reconciliationis ianuas regni celestis aperias, tibi vero commissis fratribus/sororibus simul et cunctis fidelibus de thesauro dominico nova et vetera proferas. Ad eternam salutem omnibus tua consolatione consolatis largiente gratia domini nostri ihesu christi qui cum patre et spiritu sancto vivit et regnat deus per omnia secula seculorum. Amen." Ibid., 316n827.

32 "Accipe baculum pastoralis officii et sis in corrigendis vitiis seviens in ira iudicium sine ira tenens cum iratus fueris misericordie reminiscens. Item alia. Accipe baculum sacri regiminis signum ut inbecilles consolides titubantes confirmes pravos corrigas rectos dirigas in viam salutis eterne, habeasque potestatem erigendi dignos et corrigendi indignos, cooperante domino ihesu christo qui cum patre et spiritu sancto." Ibid., 250-51. The first prayer is also found in the Dunstan Pontifical, the Benedictional of Archbishop Robert, the Egbert Pontifical, and the Lanalet Pontifical. The second prayer is found only in the first two books. See ibid., 99; Two Anglo-Saxon Pontificals, 11; Benedictional of Archbishop Robert (n. 20 above), 128; and Pontificale Lanaletense, 58. 
only the relative clauses affirming the powers of binding and loosing. ${ }^{33}$ The differences between the abbatial and episcopal versions of these prayers suggest a distinction between the powers that their beneficiaries were deemed to possess to administer correction and forgiveness: the bishop alone was invested with the same potentia that Christ conferred upon his apostles to bind and loose sins. ${ }^{34}$ However, despite these differences, the abbot was not completely divested of his penitential cura. He, like the bishop, was still charged with the "ministry of reconciliation for the lapsed and penitent."

All the prayers in the Anderson Pontifical detailed thus far, save the opening two, explicitly account for the possibility of a female consecrand through the interlineation of feminine endings. Like the abbot, the abbess was to be presented with the models of Moses and Stephen to guide her in her rule, and she was also to receive a pastoral staff and ring as visible signs of the spiritual and temporal powers that she was to exercise. Among the four remaining prayers in the ordo, two script male use - "Domine deus omnipotens exaudi preces nostras" 35 and "Respice domine super hunc famulum tuum" 36 — and two were flexible for male or female use; feminine endings were interlineated in "Omnipotens clementissime pater," 37 and the final benediction, "Aspiciat et benedicat te dominus

33 "Accipe ergo discretionis et honoris fidei signum ut que signanda sunt signes et que aperienda sunt prodas que liganda sunt liges, que solvenda sunt solves atque credentibus per fidem baptismatis lapsis autem et poenitentibus per ministerium reconciliationis ianuas regni celestis aperias cunctis vero de thesauro dominico nova et vetera proferas. Ad eternam salutem omnibus consolatus gratia domini nostri ihesu christi qui cum." "Dunstan and Brodie (Anderson) Pontificals," 251. This prayer is also found in the Dunstan Pontifical, the Benedictional of Archbishop Robert, and the Lanalet Pontifical. See ibid., 100; Benedictional of Archbishop Robert, 129; and Pontificale Lanaletense, 59. A different version of this prayer is found in the Egbert Pontifical: see Two Anglo-Saxon Pontificals, 11 .

34 See Matt. 16:19, 18:18; John 20:23.

35 "Domine deus omnipotens exaudi preces nostras et super hunc famulum tuum ill. spiritum tue benedictionis emitte. In celesti munere ditatus et tue gratiam possit maiestatis adquirere et bene vivendi aliis exemplum prebere. Per dominum." "Dunstan and Brodie (Anderson) Pontificals," 317-18.

36 "Respice domine super hunc famulum tuum ill. quem ad regimen animarum eligimus. Sit in eo domine per donum spiritus tui, prudens modestia, sapiens benignitas, gravis lenitas, casta libertas. Ferveat in caritate, et nihil extra te diligat, laudabiliterque vivat, et laudari non appetat. Te timeat. Tibi amore serviat. Tu ei honor, tu gaudium, tu in merore solacium, tu in ambiguitate consilium, tu in iniuria defensio, in tribulatione patientia, in paupertate abundantia, in ieiunio cibus, in infirmitate sis medicina. Quod est professus custodiat ut et hostem antiquum devincat et vitiorum squalores expurget quatinus electorum tuorum consortio te donante mereatur uniri. Per dominum nostrum." Ibid., 318.

37 "Omnipotens clementissime pater tuam omnipotentiam supplices deprecamur ut infundere digneris super hunc/hanc famulum/famulam tuum/tuam ill. quem/quam tuo servorum tuorum servitio mancipamus spiritum sapientie et intelligentie discretionisque dona ei in hac domo tua ita agere et iniuctum sibi temporibus officium suum administrare ut et 
rector eternus," does not refer to its beneficiary with any specific gendered nouns or adjectives. ${ }^{38}$ The absence of feminine endings in the first two prayers does not seem to have been the result of scribal oversight, as both prayers appear on the same page as the first half of "Omnipotens clementissime pater tuam omnipotentiam," which was repurposed for female use.

Read in the Anderson Pontifical, the exclusive appearance of masculine grammatical forms in "Domine deus omnipotens exaudi preces nostras" seems understandable, given that this prayer is found earlier in the manuscript, with only a slightly different incipit, as one of the blessings for use in the ordination of a deacon. ${ }^{39}$ This blessing is found in the Gregorian Sacramentary, ${ }^{40}$ as well as in all the earlier Anglo-Saxon episcopal books listed in Table $1 .^{41}$ Yet, in the Gregorian Sacramentary, the Leofric Missal, and the Egbert Pontifical, this same prayer also could be used in the ordination of a woman deacon. ${ }^{42}$ The flexibility of the prayer's use is further evinced by the fact that, in the PRG tradition, it would not only continue to be used in the ordination of a deacon, but would also be incorporated into the consecration ordines for a woman deacon and canonical abbess.

tibi placere valeat et utilitatem servorum tuorum te auxiliante perfectissime expleat propter quod hic et in futuro seculo mercedem laboris sui in consortio sanctorum tuorum et piissimo largitore percipiat. Per dominum." Ibid.

38 "Aspiciat et benedicat te dominus rector eternus et in omni parte conservet. Amen. Det tibi dominus angelum suum lucis ut conservet in te gratiam quam profudit. Amen. Mentem regat, vias dirigat, actus probet, cogitationes sanctas instruat. Amen. Opera confirmet, vota perficiet, preterrita indulgeat, presentia emundet, futura moderetur. Amen. Quietem nutriat, prospera tribuat, caritatem muniat, et ab omnibus diabolicis et humanis insidiis sua te semper protectione et virtute defendat. Amen. Et ita devotionem tuam placatus semper suscipiat ut quecumque ab eo postulaveris clementer concedat. Amen. Sit manus domini auxiliatrix tui et brachium sanctum illius opituletur tibi. Amen. Sit misericordia eius super te et pietas illius subsequatur te quod ipse prestare dignetur cuius regnum et imperium. Amen. Benedictio dei patris et filii et spiritus sancti descendat super te et pax domini sit semper tecum. Amen." Ibid., 319.

39 "Exaudi domine preces nostras et super hunc famulum tuum ill. spiritum tue benedictionis emitte ut celesti munere ditatus et tue gratiam possit maiestatis adquirere et bene vivendi aliis exemplum prebere. Per." Ibid., 238.

40 Le sacramentaire Grégorien (n. 9 above), 97, no. 31.

41 Leofric Missal (n. 19 above), 2:396-97, no. 2320; “The Dunstan and Brodie (Anderson) Pontificals," 89; Benedictional of Archbishop Robert (n. 20 above), 120; Two Anglo-Saxon Pontificals, 25; Pontificale Lanaletense, 54.

42 Le sacramentaire Grégorien, 341, no. 994; Leofric Missal, 2:422, no. 2428; Two AngloSaxon Pontificals, 25. Significantly, in the Egbert Pontifical, this prayer is found within the ordo for ordaining a deacon. The rubric heading the prayer reads: "Alia benedictio diaconi et diaconisse." Feminine endings appear in the interlinear space above the masculine grammatical forms in the main text. Aimé Martimort, Gary Macy, and Mary Schaefer have discussed the transmission of this prayer in relation to the history of women's ordination to the diaconate in the Western medieval church; see Martimort, Deaconesses: An Historical Study, trans. K. D. Whitehead (San Francisco, 1986), 202-33; Macy, Hidden History (n. 7 above), Appendix 1; and Schaefer, Women in Pastoral Office (n. 7 above), 264-312. 
But those responsible for the Anderson Pontifical's production may not have been familiar with the prayer's flexible use, or else they were limited to the script set by their exemplar(s).

The absence of interlineated feminine endings in "Respice domine super hunc famulum tuum" is more difficult to account for, as this prayer borrows nearly the entirety of a prayer that appears earlier in the manuscript, as one of the prayers that could be used for the blessing of a widow: "Deus castorum corporum benignus inhabitor." 43 This prayer also appears in the rite for blessing a widow found in the Dunstan Pontifical, the Benedictional of Archbishop Robert, and the Lanalet Pontifical. ${ }^{44}$ In the Gregorian Sacramentary, the Leofric Missal, and the Egbert Pontifical, it is even used for the blessing of a virgin. ${ }^{45}$ The theme of sexual purity and faithful love of God alone resounds throughout the portion of the prayer for a widow reiterated in the prayer for an abbot: "Lord, through the gift of your spirit, may prudent modesty, wise benignity, grave leniency, and chaste freedom be in him. May he burn in charity and love nothing apart from you.... May he keep what he has professed so that he subdues the host of ancient [enemies] and purifies the squalor of vices." Though the virtue of chastity would be commended earlier in the rite in "Omnipotens sempiterne deus, affluentem illum spiritum," it would be mentioned only in passing within a series of other virtues. The relative paucity of explicit directives to the abbot to preserve his chastity within the consecration ordo may explain why the producer(s) of the Anderson Pontifical chose to adapt the blessing of a widow for an abbot, but this explanation still does not account for the absence of interlineated feminine endings, especially given that women were the original beneficiaries of this prayer, nor does it answer the question of why this adaptation does not appear in any other English episcopal book. Thus this prayer ultimately remains a fascinating, yet perplexing, unicum.

43 "Deus castorum corporum benignus inhabitor et incorruptarum amator animarum, respice super hanc famulam tuam ill. que tibi devotionem suam offert a quo et ipsa ipsum votum assumpsit. Sit in ea domine per donum spiritus tui, prudens modestia, sapiens benignitas gravis levitas, casta libertas. Ferveat in caritate, et nihil extra te diligat, laudabiliterque vivat et laudari non appetat. Te timeat, tibi amore serviat. Tu ei honor, tu gaudium, tu in merore solacium, tu in ambiguitate consilium, tu in iniuria defensio, in tribulatione patientia, in paupertate habundantia, in ieiunio cibus, in infirmitate sis medicina. Per te quem diligere super omnia appetit quo est professa custodiat ut et hostem antiquum devincat et vitiorum squalores expurget quatinus sexagessimi fructus dono decorari virtutumque lampadibus exornari et electarum tuarum viduarum consortium te donante mereatur adipisci. Per dominum." "Dunstan and Brodie (Anderson) Pontificals," 291.

44 Ibid., 144-45; Benedictional of Archbishop Robert, 139-40; Pontificale Lanaletense, 44.

45 Le sacramentaire Grégorien, 420, no. 1254; Two Anglo-Saxon Pontificals, 118; Leofric Missal, 2:422-23, no. 2434. It should be noted that in the Leofric Missal an expanded version of this prayer appears in the rite for blessing a virgin. 
The penultimate prayer in the Anderson Pontifical's consecration ordo, "Omnipotens clementissime pater," would have highlighted again the virtues that enabled a monastic leader to administer his/her office usefully and meritoriously: sapientia, intelligentia, and discretio, three qualities repeatedly affirmed by the Benedictine Rule as essential characteristics of a good abbot. ${ }^{46}$ This prayer is found in all the stage-two English episcopal books, except in the one now housed in Douai's municipal library. Notably, in Cambridge, Corpus Christi College, MS 44, this prayer is preceded by a rubric that directs the enthronement of the consecrand: "hic mittatur abbas in cathedram et incipiat archypresul antiphonam." ${ }^{\prime 47}$ But it is difficult to determine whether the recitation of "Omnipotens clementissime pater" was meant to signal a similar ritual action in the other episcopal books containing this prayer, given that these books lack the directive for enthronement and that the prayer itself does not refer to the cathedra of the abbot/abbess.

The closing prayer, "Aspiciat et benedicat te dominus," was also included in nearly all the other stage-two English episcopal books. It contains a series of blessings that recapitulates many of the invocations of God's assistance and mercy found in earlier prayers, but for the first time in the ordo, the participation of those present at the consecration was clearly elicited. After each blessing the assembly was to proclaim Amen. This prayer concludes the entire ordo with a final Trinitarian blessing, likely made with the sign of the cross over the consecrand.

\section{Samson Pontifical}

The consecration ordo found in the Samson Pontifical contains many of the same prayers that appear in the Anderson Pontifical and in much the same order, as Table 3 shows. ${ }^{48}$ Even the final prayer in the Samson ordo, "Omnipotens

46 See especially chap. 64, which pertains to the election of the abbot: La Règle de Saint Benoît (n. 24 above), 2:648-52.

47 CCCC 44, p. 337. The presence of interlineated feminine endings in the prayer that follows this rubric suggests that an abbess was to be similarly enthroned during her consecration.

48 The Samson Pontifical, Cambridge, Corpus Christ College, MS 146, was produced at the beginning of the eleventh century, most likely at Winchester, though its script suggests that the scribe was trained at Canterbury. It then seems to have moved to Worcester during the pontificate of Samson, bishop of Worcester (1096-1112), as several additions were made to the manuscript at that time and in the style of the Worcester scriptorium. For descriptions of this manuscript, see M. R. James, A Descriptive Catalogue of the Manuscripts in the Library of Corpus Christi College, Cambridge, 2 vols. (Cambridge, 1912), 1:33235; Mildred Budny, Insular, Anglo-Saxon and Early Anglo-Norman Manuscript Art at Corpus Christi College, Cambridge, 2 vols. (Kalamazoo, MI, 1997), 1:495-99. For a summary of the arguments based on liturgical evidence that support the Winchester provenance of this manuscript, see Orchard, Sacramentary of Ratoldus (n. 25 above), ci. For 
sempiterne deus tuam omnipotentiam," is nearly identical to Anderson's "Omnipotens clementissime pater tuam omnipotentiam," save for a few minor lexical changes. But unlike the Anderson ordo, all the prayers found in Samson's explicitly account for the possibility of a female consecrand.

Similarly to the Anderson ordo, Samson's included prayers for the bestowal of the staff and ring on the consecrand, but, in the margin beside these prayers, neumed chant incipits were supplied, indicating the music that was to be sung when the insignia were bestowed. The responsory "Minor sum cunctis" was to accompany the bestowal of the staff. ${ }^{49}$ Typically, this chant appears as one of the responsories for Matins on the second Sunday of Lent. It cites, nearly verbatim, Genesis 32:10-11, which recounts the patriarch Jacob's prayer to God for deliverance from the pursuit of his brother Esau. In his prayer, Jacob mentions the baculum with which he passed over the river Jordan. The reference to Jacob's staff probably inspired the application of this Lenten chant to the consecration rite for an abbot/ abbess, for, like Jacob, the monastic leader was responsible for guiding to safety the turme under his/her care.

The antiphons to be sung during the bestowal of the ring, "Dixit autem pater ad servos suos" and "Dedit pater penitenti filio," would have conjured equally vivid scriptural associations, as both borrow from the parable of the prodigal son found in Luke's gospel. The first chant, often sung on Saturday in the second week of Lent, echoes the words spoken by the father to his servants upon his son's return: "The father said to his servants, 'Bring forth quickly the first robe and put it on him, and put a ring on his hand and shoes on his feet." 50 And the second chant, often sung on the third Sunday of Lent, first describes the father's gifts of the robe, ring, and shoes to his son as well as the great feast held to celebrate the joyous homecoming, but it then provides an allegorical reading of the parable to reveal its baptismal significance for the "we" singing: "We have the first robe and the ring, the sign of faith, in the bath [baptism]."51 This second chant's reference to the ring as a signaculum fidei would have created an obvious textual parallel with the prayer that precedes it,

paleographical arguments in favor of a Canterbury provenance, see Dumville, Liturgy (n. 19 above), 72-73; Nelson and Pfaff, "Pontificals and Benedictionals" (n. 29 above), 95-96; and L. M. Sole, "Some Anglo-Saxon Cuthbert liturgica: The Manuscript Evidence," Revue bénédictine 108 (1998): 104-44.

49 "Minor sum cunctis miserationibus tuis domine abraham in baculo meo transivi iordanem istum et nunc cum duabus turmis regredior. Libera me domine de manibus esau quia valde contremit cor meum illum timens." Can. 007156.

50 "Dixit autem pater ad servos suos cito proferte stolam primam et induite illum et date anulum in manu eius et calceamenta in pedibus eius." Can. 002280. Cf. Luke 15:22.

51 "Dedit pater penitenti filio stolam primam pariter et anulum nam et calceamenta illi tribuens celebravit magnum convivium habemus stolam primam in lavacro et anulum fidei signaculum." Can. 002136. 
but, beyond this concordance, both chants would have served to highlight an important penitential theme latent in the prayer that they frame. While the prayer would have stressed the need for the monastic leader to minister to the "lapsed and penitent," the chants would have reminded the consecrand that he/ she too was, and always would be, despite the elevation in office, a prodigal son, completely dependent on the mercy of God the Father. The reference to the lavacrum of baptism also would have recalled the associations frequently made by earlier and contemporary liturgical ordines and theological writings between baptism and monastic profession, for, by taking religious vows, one underwent a kind of second baptism that absolved all past sins. ${ }^{52}$ In hearing this chant, the abbot/abbess would have been reminded of the "baptismal" promises that he/she made at his/her profession and of the new responsibility that he/she was assuming to inspire those under his/her care to renew their own commitment to the monastic conversatio.

According to the Samson ordo, the entire consecration rite was to open with the antiphon "Exurgat deus ad nostri famulatus" before the prayer "Concede quesumus omnipotens deus" was recited. The neumed incipit to this antiphon was added in the margin next to the opening rubric to the ordo "Benedictio ad ordinandum abbatem." This antiphon does not appear in earlier or contemporary antiphoners, but it is found in English episcopal books that predate the Samson Pontifical. In the Dunstan Pontifical, the Benedictional of Archbishop Robert, and the Egbert Pontifical, it was listed as one of the antiphons that was to be sung during the dedication of a new church, while the bishop was asperging the walls of the building: "May God rise up at the solicitude of our service and increase the blessing of his holy place." 53 By opening the consecration ordo with this antiphon, the producer(s) of the Samson Pontifical (or those who created its exemplar[s]) may have sought to encourage an aural parallel between the consecration of an abbot/abbess and the dedication of a church, for both rituals marked a transition, a new beginning, in the history of a monastic or ecclesial

52 See Giles Constable, "The Ceremonies and Symbolism of Entering Religious Life and Taking the Monastic Habit, from the Fourth to the Twelfth Century," in Segni e riti nella chiesa altomedievale occidentale: 11-17 aprile 1985, 2 vols. (Spoleto, 1987), 2:771-834; and Hamilton, Practice of Penance, 77.

53 "Exurgat deus ad nostri famulatus obsequium et in loco sancto eius fiat benedictionis augmentum." "Dunstan and Brodie (Anderson) Pontificals," 179. Cf. Benedictional of Archbishop Robert, 81; Two Anglo-Saxon Pontificals, 42. According to both the Dunstan Pontifical and the Benedictional of Archbishop Robert, this antiphon was to be sung when the bishop was asperging the exterior walls of the church, and, according to the Egbert Pontifical, it was to be sung when the bishop was asperging the interior walls. It should be noted that the Dunstan Pontifical also lists this antiphon as one of the antiphons to be sung during the consecration of a cemetery: "Dunstan and Brodie (Anderson) Pontificals," 227. 
community by setting the new leader or church as the foundation for a faith community's edification.

The final chant supplied in the margins of the Samson ordo was "Beati eritis," an antiphon frequently sung on the feast of an apostle. ${ }^{54}$ It cites the beatitude from the Lukan account of Christ's sermon on the plain that promises heavenly rewards to those whose faith is met with hatred and reproach. ${ }^{55}$ So hailed by the chant, the abbot/abbess would have been cast as a bold witness to the faith, a successor to the apostles and to their predecessors, the prophets, who foretold Christ's coming. This apostolic and prophetic vocation would have been elaborated further in the benediction that was to follow this chant, "Benedicat te deus conditor celi et terre," which asks God to bless the abbot/abbess that he/ she might find rest in the seven gifts of the Holy Spirit, for so graced by the Spirit he/she would surely be able to face the challenges of abbatial rule. ${ }^{56}$ This prayer appears only in two other stage-two English episcopal books: the Claudius II and Douai Pontificals. Notably, the explicit reference to the seven gifts of the Holy Spirit is not present in later versions of the consecration ordo for an abbot, but it does resurface in the ordo for the consecration of an abbess found in stage-three English episcopal books.

"Deus lumen eternum qui inluminas" is also limited in its appearance in other stage-two episcopal books; it is found only in the Douai Pontifical. ${ }^{57}$ In the

54 "Beati eritis cum vos oderint homines et cum separaverint vos et exprobraverint et eiecerint nomen vestrum tamquam malum propter filium hominis gaudete et exsultate ecce enim merces vestra multa est in celis." Can. 001580.

55 See Luke 6:22; cf. Matt. 5:11.

56 "Benedicat te deus conditor celi et terre qui te eligere dignatus gregis sui custodiam et regimen commendare tibi voluit et te omni spiritali benedictione sanctificet ut requiescat in te septiformis eius spiritus sapientie et intellectus consilii et fortitudinis scientie et pietatis repleatque te spiritus timoris eius. Solidet tuam fragilitatem, in valitudinem roboret, pietate allevet, miseratione conservet, mentem tuam regat, vias tuas dirigat, cogitationes sanctas tibi ingerat, opera tua ipse moderando perficiat, caritatem in te edificet, sapientia te inluminet, castitate muniat, scientia instituat, fide firmet, virtutem tibi multiplicet atque in sanctitate sublimet. Ad patientiam te preparet, ad obedientia subdat, in humilitate sternat, ad continentiam det tibi fortitudinem, reddat te sobrium/sobriam, protegat pudicum/pudicam, in prosperitate temperet, in adversitate defendat, in iracundia mitiget, in iniquitate emendet, in tranquillitate corroboret, et ab omnibus vitiis et peccatis emundet, infundat in te gratiam, remittat offensam, tribuat disciplinam ut omnibus sanctis virtutibus et operibus instructus/instructa illa semper agere scias et possis unde bonam remunerationem a domino ihesu christo. Percipias illum semper habeas vivens in corde, et in die mortis ei occurras cum gaudio ut in te nihil suum repperiens inimicus confundatur, et confusus revereatur, et retrorsum erubescens avertatur, et tu stola immortalitatis indutus/induta ac per eterna secula cum sanctis regnaturus/regnatura palmam victorie gestando viventium regionem feliciter possideas. Per eum qui vivit et regnat in secula." CCCC 146, pp. 127-28.

57 "Deus lumen eternum qui inluminas omnem hominem venientem in hunc mundum maiestatem tuam cum omni supplicatione deposcimus ut hunc/hanc famulum/famulam 
Samson ordo, it was to serve as an alternate prayer to "Cunctorum ordinum institutor deus qui per moysen" and follows the prayer recited during the bestowal of the staff. Much like "Cunctorum ordinum institutor," "Deus lumen eternum" petitions God to confirm the newly elect, "who through the imposition of our hands is ordained abbot/abbess and pastor of souls with your multifold blessing." Here again, the imposition of hands was probably to be taken literally, as a cross was added in the interlinear space above "benedictione," suggesting that the bishop was to make a sign of the cross on the consecrand's forehead. ${ }^{58}$

The most notable addition to the consecration ordo found in the Samson Pontifical was the inclusion of the prayers for a mass to be celebrated after the completion of the rite. This mass also appears in the Claudius II Pontifical and in CCCC 44. In the Samson Pontifical, the mass texts follow immediately upon the consecration ordo and are headed by the rather ambiguous rubric "Missa pro abbate et congregatione commissa," but, in the other two episcopal books, the mass was identified more clearly as "Missa in consecratione abbatis." The ambiguity of the rubric in the Samson Pontifical probably derived from its exemplar(s), as the producer(s) of this manuscript may have adapted mass texts from a sacramentary for use in the consecration ordo. In the Old Gelasian Sacramentary, this mass is preceded by the rubric, "Missa in monasterio"; 59 in manuscripts of the Gregorian Sacramentary, the rubric reads, "Missa pro abbate vel congregatione"; $; 0$ and, in the late Anglo-Saxon descendants of both sacramentary traditions, like the Leofric Missal, the Winchcombe Sacramentary, and the Missal of Robert of Jumièges, the following rubrics appear, respectively: "Pro abbate et congregatione," "Pro congregatione," and "Missa pro abbate eiusque congregatione." 61 In all three Anglo-Saxon episcopal books that included this mass in

tuum/tuam N. qui/que te auctore per nostre manus inpositionem abbas/abbatissa et pastor animarum ordinatur tua multiplici benedictione confirmare digneris, et infusione gratie tue animam eius et corpus perfundas ut ab omni nevo peccati emundatus/emundata hic et in eternum tua potentissima dextera benedici mereatur. Per." Ibid., pp. 125-26.

58 It should be noted that in the Samson Pontifical's consecration rite, every time benedictio or benedicere appeared in a prayer, a cross was added in the interlinear space above the word.

59 Gelasian Sacramentary iii.l (n. 23 above), 263. This rubric also heads the same mass texts in Liber sacramentorum Gellonensis (n. 11 above), 403, no. 396.

60 Le sacramentaire Grégorien lxxiv (n. 9 above), 435.

61 Leofric Missal (n. 19 above), 2:335; Anselme Davril, ed., The Winchcombe Sacramentary, HBS 109 (London, 1995), 220; H. A. Wilson, ed., The Missal of Robert of Jumièges, HBS 11 (London, 1896), 250. The Winchcombe Sacramentary, Orléans, Bibliothèque municipale, MS 127 (105), is a Gregorian Sacramentary that was produced in the late tenth century at either Ramsey or Winchcombe. See R. Pfaff, "Massbooks: Sacramentaries and Missals," in Liturgical Books, 7-34, at 14; Orchard, Sacramentary of Ratoldus (n. 25 above), lxi-lxiii. The Missal of Robert of Jumièges, Rouen, Bibliothèque municipal, MS 274 (Y.6), is a Gregorian Sacramentary that was produced in the early eleventh century from a copy of a sacramentary from Peterborough or Ely. It is named after its eventual owner, Robert, 
their consecration ordo for an abbot/abbess, the mass was to open with the collect "Omnipotens sempiterne deus qui facis mirabilia magna" 62 and close with the postcommunion "Quos celesti recreasti munere perpetuo." 63 In the Claudius II Pontifical and in CCCC 44, the secret "Hostias domine famulorum tuorum placatus intende" is identical with the version found in earlier sacramentaries, ${ }^{64} \mathrm{but}$, in the Samson Pontifical, it appears with a few minor variants. ${ }^{65}$ The Claudius II Pontifical and CCCC 44 even supplied the incipit to the preface that was to be recited during the canon of the mass: "Vere dignum, eterne deus. Propitiare domine supplicationibus nostris." 66 All three episcopal books scripted the bestowal of a blessing after communion. In the Samson and Claudius II Pontificals, this blessing, "Aspiciat et benedicat te dominus rector eternus," is essentially the same as the one that appears in the Anderson Pontifical, ${ }^{67}$ but in CCCC 44, a different blessing, "Benedicat in te dominus imaginem," had to be provided because "Aspiciat et benedicat" was to be said at the conclusion of the consecration rite proper. ${ }^{68}$ None of the prayers that appear in these three consecration masses were exclusive of a female beneficiary as feminine endings were thoroughly interlineated.

bishop of London (1044-51) and then archbishop of Canterbury (1051-52). See Pfaff, "Massbooks," 15-19; and Orchard, Sacramentary of Ratoldus, lxii.

62 "Omnipotens sempiterne deus qui facis mirabilia magna solus pretende super famulum/famulam tuum/tuam ill. abbatem/abbatissam et super cunctam congregationem illi commissam spiritum gratie salutaris et ut in veritate tibi complaceant perpetuum eis rorem tue benedicitonis infunde. Per." CCCC 146, p. 129. Cf. D. H. Turner, ed., The Claudius Pontificals, HBS 97 (London, 1971), 108; CCCC 44, pp. 339-40.

63 "Quos celesti recreasti munere perpetuo domine presidio comitare et quos non desinis fovere dignos fieri sempiterna redemptione concede. Per." CCCC 146, p. 129. Cf. Claudius Pontificals, 109; CCCC 44, p. 341.

64 "Hostias domine famulorum/famularum tuorum/tuarum placatus intende et quas in honorem nominis tui devota mente pro eis celebramus proficere sibi sentiant ad salutem. Per." Claudius Pontificals, 108. Cf. CCCC 44, p. 340.

65 "Hostias domini famuli/famule tui/tue ill. abbatis/abbatisse famulorumque/famularumque tuorum/tuarum illi commissorum/commissarum placatus intende ut quas in honorem nominis tui devota mente pro eis celebramus proficere sibi sentiant ad medelam. Per." CCCC 146, p. 129.

66 "VD. eterne deus. Propitiare domine supplicationibus nostris et miserere famulo/ famule tuo/tue abbati/abbatisse et omni congregationi sibi commisse ut cunctis sceleribus eorum amputatis. Ita sint tue miserationis defensione protecti ut in observatione mandatorum tuorum mereantur esse perfecti. Quatinus universis in hac vita facinoribus careant et ad conspectum glorie tue quandoque sine confusione perveniant. Per christum." Claudius Pontificals, 108. Cf. CCCC 44, p. 340. This preface is also found in the Leofric Missal as the preface to the "missa pro omnibus fidelibus vivis": Leofric Missal, 2:352, no. 2116.

67 See n. 38 above. Cf. CCCC 146, p. 129; Claudius Pontificals, 108-9.

68 "Benedicat in te dominus imaginem quam plasmavit et det misericordiam quam promisit. Amen. Custodiat animam tuam quam redemit servando in te gratiam quam profudit. Amen. Ut et tu impleas que precepit et ille custodiat quod donavit teque perducat ad regna celorum ubi letari dignus sis sine fine cum cetibus angelorum. Amen." CCCC 44, pp. 340-41. 


\section{Claudius II Pontifical}

Many of the prayers and chants included in the Samson Pontifical are found in the Claudius II Pontifical, and, discounting the addition and subtraction of a few prayers, the sequence of prayers unfolds in much the same way. ${ }^{69}$ Also like the Samson Pontifical, feminine endings were interlineated throughout all the prayers contained in Claudius II's ordo for use in the consecration of an abbess. Notable departures from the Samson ordo include a rubric directing the bestowal of a copy of the Benedictine Rule with an accompanying prayer, "Accipe regulam a sancto benedicto abbate," which would have reminded the abbot/abbess of the monastic tradition that he/she had to uphold when "ruling and safeguarding the flock entrusted to [him/her] by God."70 This prayer is found in only one other English episcopal book: CCCC 44. ${ }^{71}$ Claudius II's ordo also contains the unusual "Deus honorum omnium largitor deus," which asks for the outpouring of God's grace so that "[the abbot/abbess] may wholly accomplish the pastoral care and rule of monastic people."72 Only the Douai Pontifical also includes this prayer, in the same position after the prayer recited at the bestowal of the ring. ${ }^{73}$

Four chant texts were provided in Claudius II's ordo. One corresponds with the chants listed in the Samson Pontifical: the antiphon "Dedit pater penitenti filio," which was to be sung after the bestowal of the ring. ${ }^{74}$ A different antiphon was

69 The Claudius II Pontifical, London, BL, MS Claudius A.iii, fols. 9-18, 87-105, was produced at Christ Church, Canterbury either in the second quarter of the eleventh century, according to its editor, D. H. Turner, or in the middle of the eleventh century, according to Helmut Gneuss, Michael Lapidge, and David Dumville. See Turner, Claudius Pontificals, xxix; Gneuss, "Liturgical Books in Anglo-Saxon England and Their Old English Terminology," in Learning and Literature in Anglo-Saxon England: Studies Presented to Peter Clemoes on the Occasion of His Sixty-fifth Birthday, ed. M. Lapidge and H. Gneuss (Cambridge, 1985), 91-141, R.7; Lapidge, Anglo-Saxon Litanies of the Saints, HBS 106 (London, 1991), 69; and Dumville, Liturgy (n. 19 above), 77-78. See also Nelson and Pfaff, "Pontificals and Benedictionals" (n. 29 above), 92. The close correspondences between the Samson and Claudius II Pontificals fit well with other evidence for the activities of liturgists at Canterbury in the central Middle Ages, much of which is summarized in Helen Gittos, "Sources for the Liturgy of Canterbury Cathedral in the Central Middle Ages," in Medieval Art, Architecture, and Archaeology at Canterbury, ed. Alixe Bovey (Leeds, 2013), 41-58.

70 "Accipe regulam a sancto benedicto abbate nobis traditam ad regendum/regendam custodiendumque/custodiendamque gregem tibi a deo creditum. In quantum te deus ipse confortaverit ac fragilitas humana permiserit. Per." Claudius Pontificals, 103-4.

71 CCCC 44, p. 329.

72 "Deus honorum omnium largitor, deus omnium dignitatum distributor, huic famulo/ famule tuo/tue N. quem/quam dominici gregis abbatem/abbatissam elegisti. Hanc quesumus domine gratiam misericorditer largire, ut ad curam pastoralem et ad regendam monasticam plebem te miserante usquequaque proficiat. Per." Claudius Pontificals, 106.

73 Douai, Bibliothèque municipale, MS 67, fol. 85v.

74 Claudius Pontificals, 106. 
supplied for the bestowal of the staff — "Iustus ut palma florebit" 75 — with an alternate responsory, "Propter veritatem," added marginally. The responsory was probably to be used instead of the antiphon during the consecration of an abbess, given that this chant text was copied by the same scribe who interlineated feminine endings throughout all the prayers. ${ }^{76}$ This gender distinction between the chants seems to be supported further by their customary appearance within the Western church's liturgical cursus. The antiphon was typically sung on the feast of a martyr, the responsory on the feast of a virgin. Both chants are direct citations of Psalm verses: Psalm 91:13 and Psalm 44:5, respectively. Knowledge of the entirety of the Psalms from which these verses were extracted would have heightened the chants' gendered associations: the abbot with the iustus of Psalm 91, who is planted and flourishes in the house of the Lord, the abbess with the filia of Psalm 44, who is taken from her family to be splendidly adorned for her nuptials to the king. Significantly, CCCC 44 also scripted the antiphon "Iustus ut palma florebit" as the chant to be sung after the bestowal of the staff, but it was to accompany the consecration of an abbot or an abbess; no feminine alternative was supplied in the main text or marginally. ${ }^{77}$ Thus the Claudius II Pontifical, with the marginal addition of the responsory "Propter veritatem" introduced a gender distinction into the consecration rite that was not present in any other stage-two version of the ordo. Though admittedly a relatively minor distinction, it does presage the division of the consecration ordo according to gender that ultimately occurred in English episcopal books, beginning in the third quarter of the eleventh century.

The fourth chant added to Claudius II's ordo was the antiphon "Sancte benedicte confessor domini." 78 In a few antiphoners, this chant imploring Benedict's intercession was reserved for the dies natalis and translatio of Benedict of Nursia (21 March and 11 July). Thus it is fitting that in Claudius II's ordo it was to be sung after the bestowal of the Benedictine Rule. CCCC 44 also included this chant in the very same place in its ordo, but here it was identified as a responsory, not as an antiphon. ${ }^{79}$

CCCC 44

In terms of its prayers and chants, the consecration ordo found in CCCC 44 contains many of the texts found in earlier Anglo-Saxon episcopal books, especially

75 Ibid., 105; "Iustus ut palma florebit et sicut cedrus libani multiplicabitur." Can. 003552 .

76 Claudius Pontificals, 105n1; "Propter veritatem et mansuetudinem et iustitiam et deducet te mirabiliter dextera tua." Can. 007441.

77 CCCC 44, p. 334.

78 Claudius Pontificals, 104; "Sancte benedicte confessor christi pro nostra omniumque salute intercede." Can. 602077.

79 CCCC 44, p. 329. 
those found in its near contemporary, the Claudius II Pontifical. ${ }^{80}$ Both books were produced at Canterbury in roughly the middle of the eleventh century, and their consecration ordines were entirely applicable to either an abbot or an abbess. Despite their many similarities, significant differences between both books' ordines can be detected. Among the most apparent differences is the explicit application of the prayer "Omnipotens clementissime pater tuam omnipotentiam" to the enthronement of an abbot/abbess, as was mentioned earlier. ${ }^{81}$ The version of this prayer found in CCCC 44 also contains changes to a line found in the middle of the prayer, which would have helped to make its monastic usage clearer. Instead of petitioning God to "grant him a spirit of wisdom, understanding, and discretion in this, your house, so as to act and administer his office enjoined on him for the time," CCCC 44's version asks, "grant him/her a spirit of wisdom, understanding, and discretion so as to lead and benefit your holy flock and administer the office of abbot enjoined on him/her worthily during his/ her time." 82

The antiphon "Redemptor mundi" was to accompany the enthronement of the abbot/abbess. This antiphon does not appear in any of the liturgical books containing music for the Divine Office and Mass that have been catalogued thus far by the contributors to the Cantus Database; however, a versicle with the incipit "Redemptor mundi salva nos" is found in a twelfth-century antiphoner

80 CCCC 44 was produced at Canterbury sometime between the middle and second half of the eleventh century. Scholars are divided over the question of its precise provenance. D. H. Turner, David Dumville, Janet Nelson, and Richard Pfaff have ascribed a Christ Church, Canterbury provenance. Dumville has suggested that this "grand but thoroughly AngloSaxon manuscript ... might seem to attach itself quite naturally to the person of Stigand," bishop of Winchester (1047-70) and archbishop of Canterbury (1052-70). Turner, Claudius Pontificals, xxxvii; Dumville, Liturgy (n. 19 above), 92; Nelson and Pfaff, "Pontificals and Benedictionals" (n. 29 above), 92. Conversely, M. R. James, T. A. M. Bishop, Michael Lapidge, and Mildred Budny have endorsed a St. Augustine's, Canterbury provenance on the basis of the book's script and certain liturgical features, especially the saints invoked in its three litanies. James, Descriptive Catalogue (n. 48 above), 1:88-90; Bishop, "Notes on Cambridge Manuscripts: Part V: MSS. Connected with St Augustine's Canterbury Continued," Transactions of the Cambridge Bibliographical Society 3 (1959): 93-95; Lapidge, Anglo-Saxon Litanies, 63; Budny, Insular, Anglo-Saxon and Early-Norman Manuscript Art (n. 48 above), 1:675-85, at 677. Perhaps significantly, Dumville was unwilling to grant Bishop's localization of the manuscript "even if the scribal identification is correct," citing "the vexed question of whether we may reasonably admit an origin in an abbey for a specifically episcopal book" (Liturgy, 92). The recent research of Henry Parkes on the production of an early eleventh-century episcopal book at St. Alban's, Mainz (Vienna, Österreichische Nationalbibliothek, MS 701) should encourage scholars to reconsider the possibility of a monastic provenance for certain episcopal books: Making of Liturgy (n. 3 above), pt. 4 .

81 CCCC 44, pp. 337-38. See n. 47 above.

82 "Spiritum sapientie et intellegentie discretionisque dona ei ita sancto gregi tuo preesse et prodesse ut [sic] iniunctum sibi abbatis officium suis temporibus digne administrare" (emphasis mine). Ibid., 338. 
from Florence Cathedral for Vespers on the feast of the Image of the Lord (9 November). ${ }^{83}$ It is possible that, as more of the chants in medieval liturgical manuscripts are edited and catalogued, an earlier witness to "Redemptor mundi salva nos" will be discovered.

CCCC 44 also features a new prayer, "Omnipotens piissime et misericordissime domine," as one of the prayers that could be read after the bestowal of the Benedictine Rule; it was to serve as an alternate to "Deus qui sub tue maiestatis arbitrio" and "Super hunc famulum tuum domine quesumus." 84 This new prayer invokes the intercession of "[God's] beloved, Benedict, pious father and our pastor," so that God would bestow his blessing more abundantly upon the elect and inspire him/her to be clement, prudent, docile, wise, just, obedient, edifying, and beneficial in every way to those souls entrusted to his/her care. The end of the prayer refers to the "multiplied profit of the loaned talent," recalling the parable of the talents and the closing lines to the prayer "Cunctorum ordinum institutor deus qui per moysen," which was to be recited after the bestowal of the staff according to CCCC 44 's ordo.

A different version of the prayer for the bestowal of the staff appears in this rite. CCCC 44's "Accipe baculum pastoralis cure" retains the earlier version's admonition to balance mercy with righteous anger when correcting vices, but it lacks the series of commands to the consecrand to solidify the weak, strengthen the faltering, correct the crooked, and direct the upright, all of which echoed the related prayer recited at a bishop's ordination. ${ }^{85}$ Notably, "Cunctorum ordinum institutor deus qui per moysen," the prayer that was to follow, seems

83 Florence, Arcivescovado - Biblioteca, s.c.; Can. 800372.

84 "Omnipotens piissime et misericordissime domine deus noster maiestatem tuam suppliciter exoramus et petimus super hunc/hanc famulum/famulam tuum/tuam ill. qui/que ex providentia tue dispositionis ad regimen animarum hodie rector et pastor assumitur et eligitur ut et tue benedictionis ei infusionem per intercessionem dilecti tui benedicti pii patris ac pastoris nostri per plenissimam largitatem infundas tuaque eum/eam misericordia iugiter preveniat et subsequatur ut quem/quam ad gubernandum gregem tuum preesse disposuisti. In mensa tue miserationis clementia facias ubique circumdari et muniri. Da ei domine cor prudens et docibile. Gratia tue sapientie mentem eius adimple ut sciat et intellegat iuste familiam tuam disponere tuam voluntatem, in precibus tenere, et sibi subiectis in operibus suis edificationem prebere, et in omnibus ubique modis commissis animabus ad vitam prodesse. Infunde ei domine timorem et amorem tuum ut te diligat, te timeat, secundum te sapiat, secundum te vivat, secundum te disponat et ordinet, per te curat, ad te perveniat. Non sit de officii iniuncti tempore et neglegentia a te iudicandus/iudicanda sed de crediti talenti lucro multiplicato a te perpetua remuneratione gratuletur fideliter donandus/ donanda. Per dominum." CCCC 44, pp. 330-31.

85 "Accipe baculum pastoralis cure quem preferas caterve tibi commisse ad exemplum iuste severitatis et correctionis. Accipe inquam baculum sacri monastici regiminis et sis in corrigendis vitiis mitescens in ira iudicium sine furore tenens et cum iratus fueris misericordie reminiscens. Prestante domino nostro ihesu christo qui cum patre et spiritu sancto." Ibid., $333-34$. 
to have been adapted from the version found in the Samson and Claudius II Pontificals in order to highlight better the ritual action that was to precede it. In the middle of the prayer, two references to the baculum were inserted, and, in the first, it was described further as a "sign of religion and correction." 86

A similar adaptation was made to "Omnipotens sempiterne deus affluentem," the prayer that was to be said after the bestowal of the ring. Near the beginning of the prayer, immediately following the petition that the newly elected abbot/abbess "never be separated from God's grace," CCCC 44's version added: "but fortified all around with the integrity of faith by accepting this ring." made to the prayer to give it a more discernibly monastic cast. The example of Stephen, the "Levite elected by the apostles," was replaced with "God's innumerable elected servants [who] were abbots, who merited to serve [God] and endure without end in their holy service according to the institutes of holy father Bene-

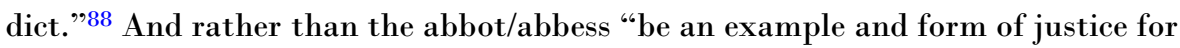
governing and ruling the church [ecclesiam] faithfully," he/she was to "be an example and form of justice for governing and ruling the monastic flock [monasticum gregem] entrusted to him/her." 89 Finally, the bishop was no longer to petition that the abbot/abbess be effective in his/her application of "censura discipline" more generally but of "monastice censura discipline" more specifically. ${ }^{90}$ Notably, the same alterations, save the last, also appear in the Claudius II Pontifical's version of "Omnipotens sempiterne deus affluentem." 91

The motivations behind the changes made to the prayers found in CCCC 44's ordo are not immediately detectable on the manuscript page, nor is it clear that the producer(s) of this manuscript were the ones who introduced these changes, though it is very common to find this kind of thorough reworking in CCCC 44. At a minimum, the additional references to Benedict, the monastic flock, and the abbatial office reflect a concerted effort to make the prayers and insignia of the rite more unambiguously monastic in their application. Even the version of the blessing "Aspiciat et benedicat te dominus rector eternus" was to end

86 "Percipiens baculum religionis et correctionis signum quem parvitatis nostre electione et manus nostre inpositione hodie monachorum/sororum abbatem et ovium tuarum pastorem esse constituimus tua benedictione per omnia dignus existat sicque baculo isto monasticum gregem sibi commendatum sub tua gubernatione regat." Ibid., 334 .

87 "Numquam postmodum a tua gratia separetur sed per acceptionem huius anuli integritate fidei circumquaque munitus/munita." Ibid., 336. The part in italics is unique to CCCC 44.

88 "Electi servi tui innumeri exstiterunt abbates qui secundum instituta sancti patris benedicti meruerunt tibi servire et in tuo sancto servitio sinetenus perdurare." Ibid. This line replaces "levita electus ab apostolicis sanctus stephanus meruit perdurare," found in earlier versions of this prayer.

89 "Sit exemplum et forma iustitie ad gubernandum regendumque monasticum gregem sibi creditum" (emphasis mine). Ibid., 337.

90 Ibid.

91 Cf. Claudius Pontificals, 106-7. 
with a final affirmation of Benedict's exemplarity. ${ }^{92}$ Such additions would have been fitting if this manuscript was produced within the monastic scriptorium of St. Augustine's Canterbury, as M. R. James and T. A. M. Bishop claimed. But all these changes may have been introduced to do more than simply clarify the monastic character of the prayers and insignia. Their aim may also have been to dampen the potential resonances between the rites for the ordination of a bishop and the consecration of an abbot/abbess, thereby demarcating more unmistakably the respective temporal and spiritual jurisdictions of these leaders. According to CCCC 44, an abbot's/abbess's domain did not encompass the "church" more broadly but was limited to the monastery, and the censure that he/she was allowed to apply to his/her community was circumscribed by a "monastic" modifier, perhaps suggesting that the discipline that an abbot/ abbess could apply was not necessarily "sacramental" in its effect, unless the leader were also ordained to the priesthood.

The defense of vested episcopal prerogatives could have played an instrumental role in introducing the changes found in CCCC 44's consecration ordo, especially if this manuscript was produced for and used by the archbishop of Canterbury, as D. H. Turner, David Dumville, Janet Nelson, and Richard Pfaff have argued. From the late tenth century on, such prerogatives were increasingly being challenged on the Continent by abbots of powerful monasteries like Fleury and Cluny, which sought full exemption from their diocesans. ${ }^{93}$ These bids for independence may have aroused concern among some English bishops and motivated them to remind future abbots and abbesses in their dioceses of their proper place under episcopal control through the very prayers recited at their consecrations. Certainly the form that the consecration ordo came to assume in late eleventhand twelfth-century English episcopal books emphasized even more dramatically the different powers bestowed on a bishop, abbot, and abbess.

92 "Ut cum sancto benedicto abbate omnibusque sanctis capias partem beatitudinis eterne. Amen." CCCC 44, p. 339.

93 Barbara Rosenwein has studied the historical development of such privileges granted to monasteries on the Continent in Negotiating Space: Power, Restraint, and Privileges of Immunity in Early Medieval Europe (Ithaca, NY, 1999). Elizabeth Dachowski has most recently examined the development of Fleury's privileged status during the abbacy of Abbo (988-1004) in First among Abbots: The Career of Abbo of Fleury (Washington, DC, 2008). For the development of Cluny's exempt status, see H. E. J. Cowdrey, The Cluniacs and the Gregorian Reform (Oxford, 1970), 22-36; Giles Constable, "Cluny in the Monastic World of the Tenth Century," in Il secolo di ferro: mito e realtà del secolo X (Spoleto, 19-25 aprile 1990), Settimane di studio del Centro italiano di studi sull'alto medioevo 38 (Spoleto, 1991), 391-437, at 416-19; and Dominique Iogna-Prat, Order and Exclusion: Cluny and Christendom Face Heresy, Judaism, and Islam (1000-1150) (Ithaca, NY, 2002), 55-60. J.-F. Lemarignier more broadly examined the development of exemption in Normandy; see Étude sur les privilèges d'exemption et de juridiction ecclésiastique des abbayes normandes depuis les origines jusqu'en 1140 (Paris, 1937). 


\section{Douai Pontifical}

With respect to its date of production, the Douai Pontifical is an outlier among stage-two English episcopal books. It was copied sometime in the first half of the twelfth century at Christ Church, Canterbury, but its ordo for the consecration of an abbot, like many other rites found in this liturgical book, is incongruous with the dating of the manuscript. ${ }^{94}$ All the prayers can be found in versions of the ordo that date to the first half of the eleventh century, though none of them were inclusive of feminine grammatical forms for an abbess. Only the insignia of the staff and ring were to be bestowed on the abbot; no chant incipits were supplied to accompany the bestowal of these insignia, nor was a concluding consecration mass scripted. Compared to the ordo found in episcopal books produced in the late eleventh and early twelfth centuries, the Douai ordo appears quite archaic. Whether it was ever used in practice is difficult to determine; undoubtedly it would have been quickly superseded by the episcopal books newly transmitted from the Continent during this period, likely rendering it a relic of an earlier Anglo-Saxon past.

\section{Stage-Three English Episcopal Books}

During the reign of Edward the Confessor (1044-1066), possibly through the travels of Ealdred, archbishop of York (1060-1069), an episcopal book containing the ordines belonging to the PRG tradition was transmitted to England. ${ }^{95}$ London, BL, MS Cotton Vitellius E.xii may derive from the copy that Ealdred carried back with him from his visit to the Rhineland. At least five other Anglo-Saxon manuscripts attest to the dissemination of the PRG's ordines in England: Oxford, Bodleian Library, MS Bodley 579 (Leofric Missal); Cambridge, Corpus Christi College, MS 163; London, BL, MS Tiberius C.i; London, BL, MS Cotton Vitellius A.vii; and, Cambridge, Corpus Christi College, MS 265. ${ }^{96}$ The PRG's consecration ordines for an abbot and abbess were not included, or no longer survive, in any of these manuscripts; however, close textual analysis of the episcopal books belonging to the third stage in the development of the

94 Leroquais, Les Pontificaux manuscrits (n. 25 above), 1:148-55; Wilson, Benedictional of Archbishop Robert (n. 20 above), xix-xx; and Gittos, "Sources for the Liturgy of Canterbury" (n. 69 above), 51-52.

95 Michael Lapidge, "Ealdred of York and MS Cotton Vitellius E.xii," Yorkshire Archaeological Journal 55 (1983): 11-25; Nelson and Pfaff, "Pontificals and Benedictionals" (n. 29 above), 96.

96 For descriptions of these manuscripts, see Christopher Jones, "The Chrism Mass in Later Anglo-Saxon England," in The Liturgy of the Late Anglo-Saxon Church, ed. Helen Gittos and M. Bradford Bedingfield (London, 2005), 105-42, at 141-42; and Nelson and Pfaff, "Pontificals and Benedictionals," 96-97. 
consecration ordines, listed in Table 1, demonstrates a clear dependence on the PRG tradition.

The first manuscript witness to the third stage in development is the Tiberius MS mentioned above. ${ }^{97}$ Later additions were made to this manuscript in the final quarter of the eleventh century at Sherborne and then Salisbury. Among the additions made at Salisbury were the consecration ordines for an abbot and abbess. ${ }^{98}$ These ordines incorporate many of the prayers found in the PRG's ordines, but lexical changes to some prayer texts and the absence of any alia (or alternate prayers) suggest that the Tiberius MS's ordines are distinct and, thus, represent a new stage in the development of the consecration rite. They are nearly perfectly identical with those found in other English episcopal books produced in the late eleventh and twelfth centuries, which include: Dublin, Trinity College, MS 98 (B.3.6); Cambridge, Trinity College, MS B.11.10; Oxford, Magdalen College, MS 226; Cambridge, University Library, MS Ll.2.10; London, BL, MS Cotton Vespasian D.xv; London, BL, MS Cotton Tiberius B.viii; and, Cambridge, University Library, MS Ee.2.3. ${ }^{99}$ Collation of the prayers and rubrics of these ordines reveals very minimal textual variation, suggesting a concerted and successful effort made by English bishops, particularly the liturgists at Christ Church, Canterbury, to regularize the consecration rites for abbots and abbesses. Given the regular appearance of these ordines, I will consider them as a collective in what follows, and Henry Wilson's edition of the Magdalen College MS will serve as the base text for the rubrics and prayers. ${ }^{100}$

Several features of the PRG's consecration ordines had a lasting effect on those that succeeded them. With the dissemination of the PRG's ordines over the

97 The portion of London, BL, MS Cotton Tiberius C.i, fols. 43-203, that contains episcopal rites was initially copied by two scribes in Germany in the middle of the eleventh century, but it was subsequently used in Sherborne and then in Salisbury when the diocese moved there in 1078. Significant additions were made to the manuscript in blank spaces and on added leaves by thirteen scribes writing in England between 1070 and 1100. Nelson and Pfaff, "Pontificals and Benedictionals," 96-97; Richard Gameson, The Manuscripts of the Early Norman Period (c. 1066-1130) (Oxford, 1999), nos. 404 and 405; Jonathan Wilcox, Anglo-Saxon Manuscripts in Microfiche Facsimile, vol. 8, Wulfstan Texts and Other Homiletic Material (Tempe, 2000), 30-45, which includes an extensive bibliography.

98 These ordines, along with the consecration of a virgin, were copied by scribe 11, according to Jonathan Wilcox's numeration of the hands operative in the Tiberius MS. It should be noted that another consecration ordo for an abbess appears in the original part of the manuscript copied by German scribes (fols. 89v-93r), but this ordo bears little resemblance to the ordo found in episcopal books of the PRG tradition, and, arguably, it was replaced by the ordo later copied in the manuscript by the Salisbury scribe.

99 For the dating and provenance of these manuscripts, see H. A. Wilson, ed., The Pontifical of Magdalen College, HBS 39 (London, 1910), xiv-xxxi; J. Brückmann, "Latin Manuscript Pontificals and Benedictionals in England and Wales," Traditio 29 (1973): 391-458; and Gittos, "Sources for the Liturgy of Canterbury," 52-53.

100 Wilson, ed., Pontifical of Magdalen College. 
eleventh and twelfth centuries, an irreversible split occurred in the consecration rite for an abbot and abbess. They became two independent rituals with markedly distinct scripts: different prayers, a separate interrogation for an abbot, and the bestowal of different insignia - the Rule and staff for an abbot, only the Rule for an abbess. Episcopal books in the PRG tradition even contain different ordines for the consecration of an abbess professing the monastic rule and an abbess professing the rule of canons. ${ }^{101}$ Mary Schaefer has analyzed the PRG's ordines for the consecration of both kinds of abbesses and a woman deacon for their ritual and textual parallels. ${ }^{102}$ Notably, in stage-three English episcopal books, only one ordo for the consecration of an abbess appears, and it includes all the prayers from the PRG's ordo for a canonical abbess, save one. Given the many similarities between the PRG's ordines for an abbot and a monastic abbess, the latter ordo was likely not favored by those who wished to make the male and female versions of the consecration rite distinct; thus, it was ultimately supplanted by the ordo for a canonical abbess, which shares very few correspondences with the ordo for an abbot.

Table 4 compares the ordines for the consecration of an abbot and abbess in the PRG and stage-three English episcopal books. According to both traditions, the performance of these ordines was to take place within the context of the celebration of mass. ${ }^{103}$ However, the opening rubrics to the ordines in stage-three episcopal books state that the consecration of an abbot was to take place before the gospel reading and the consecration of an abbess after it. ${ }^{104}$ This distinction was not made in the PRG's ordines; all three consecration rites were to be carried out before the gospel reading. ${ }^{105}$ At the beginning of the consecration rite proper, both an abbot and abbess were to prostrate themselves before the altar in the company of two or three of their community members, ${ }^{106}$ but in the ordo for an abbot, prior to this ritual act, the newly elect was interrogated by the bishop to test his fidelity to the Benedictine Rule: his commitment to maintain justice in his community, to extend hospitality to pilgrims and the poor, and to foster humility and patience in both word and deed, as well as his willingness to

101 For the critical edition of these ordines, see Le pontifical romano-germanique (n. 4 above), 1:XXII (canonical abbess), XXVI (abbot), XXXII (monastic abbess). As Table 4 shows, the ordo for the consecration of an abbot in the four manuscripts belonging to Group II of Vogel and Elze's edition of the PRG - B, G, K, and L - was partially adapted for the consecration of an abbess. The same manuscripts also contain the ordines for the consecration of a canonical and monastic abbess.

102 Schaefer, Women in Pastoral Office (n. 7 above), 280-99.

103 Pontifical of Magdalen College, 81, 87; Le pontifical romano-germanique, 1:XXVI.1, XXII.1.

104 Pontifical of Magdalen College, 81, 87.

105 Le pontifical romano-germanique, 1:XXVI.2, XXII.2.

106 Pontifical of Magdalen College, 82, 87. 
Table 4: Comparison of the prayers and ritual actions comprising the ordines for the consecration of an abbot and abbess found in the PRG and stage-three English episcopal books

\begin{tabular}{|c|c|c|c|c|c|}
\hline \multirow[b]{2}{*}{$\begin{array}{l}\text { Episcopal } \\
\text { Book }\end{array}$} & \multicolumn{2}{|c|}{ Ordines for the Consecration of an Abbot } & \multicolumn{3}{|c|}{ Ordines for the Consecration of an Abbess } \\
\hline & $\overline{\text { PRG }}$ & $\begin{array}{l}\text { Stage-Three Episcopal } \\
\text { Books }\end{array}$ & $\overline{\text { PRG }}$ & & $\begin{array}{l}\text { Stage-Three Episcopal } \\
\text { Books }\end{array}$ \\
\hline $\begin{array}{l}\text { Opening } \\
\text { Rubric }\end{array}$ & Ordinatio abbatis & In abbatis ordinatione & $\begin{array}{l}\text { Ordinatio abbatisse } \\
\text { monasticam } \\
\text { regulam profitentis }\end{array}$ & $\begin{array}{l}\text { Ordinatio abbatisse } \\
\text { canonicam regulam } \\
\text { profitentis }\end{array}$ & $\begin{array}{l}\text { Incipit benedictio } \\
\text { abbatisse }\end{array}$ \\
\hline \multirow[t]{5}{*}{$\begin{array}{l}\text { Prayers and } \\
\text { Ritual } \\
\text { Actions }\end{array}$} & $\begin{array}{l}\text { (During mass, before the } \\
\text { gospel reading) }\end{array}$ & $\begin{array}{c}\text { (During mass, before } \\
\text { the gospel reading) }\end{array}$ & $\begin{array}{l}\text { (During mass, before } \\
\text { the gospel reading) }\end{array}$ & $\begin{array}{l}\text { (During mass, before the } \\
\text { gospel reading) }\end{array}$ & $\begin{array}{l}\text { (During mass, after the } \\
\text { gospel reading) }\end{array}$ \\
\hline & $\begin{array}{l}\text { (Interrogation of abbot } \\
\text { by bishop) }\end{array}$ & $\begin{array}{l}\text { (Interrogation of } \\
\text { abbot by bishop) }\end{array}$ & & & \\
\hline & $\begin{array}{l}\text { 1. Concede quesumus } \\
\text { omnipotens Deus }\end{array}$ & $\begin{array}{l}\text { 1. Concede quesumus } \\
\text { omnipotens Deus }\end{array}$ & $\begin{array}{l}\text { 1. Concede quesumus } \\
\text { omnipotens Deus }\end{array}$ & $\begin{array}{l}\text { 1. Exaudi domine preces } \\
\text { nostras et super hanc } \\
\text { famulam tuam }\end{array}$ & $\begin{array}{l}\text { 1. Exaudi domine preces } \\
\text { nostras et super hanc } \\
\text { famulam tuam }\end{array}$ \\
\hline & (Bestowal of Rule) & (Bestowal of Rule) & & & \\
\hline & $\begin{array}{l}\text { 2. Accipe regulam a } \\
\text { sanctis patribus } \\
\text { nobis }\end{array}$ & $\begin{array}{l}\text { 2. Accipe regulam a } \\
\text { sanctis patribus } \\
\text { nobis }\end{array}$ & & $\begin{array}{l}\text { 2. Omnipotentiam tuam } \\
\text { domine humiliter } \\
\text { imploramus }\end{array}$ & $\begin{array}{l}\text { 2. Omnipotentiam } \\
\text { tuam domine humi- } \\
\text { liter imploramus }\end{array}$ \\
\hline
\end{tabular}

(Bestowal of Staff) (Bestowal of Staff) 
3. Accipe baculum pas- 3. Accipe baculum toralitatis pastoralis officii

(Consecration when an abbot or abbess is ordained in a monastery)

4. Cunctorum operum institutor deus qui per moysen

\section{(Imposition of}

Hands)

5. Omnipotens sempiterne deus affluentem spiritum tue benedictionis famulo tuo

5b. Alia. Deus omnium fidelium pastor et rector

. Cunctorum

\section{(Imposition of}

Hands)

5. VD eterne deus tuum bonorum institutor deus qui per moysen affluentem spiritum tue benedictionis super hunc famulum

2. Cunctorum bonorum institutor deus qui per moysen

(Imposition of

Hands)

3. Omnipotens sempiterne deus affluentem spiritum tue benedictionis famule tue

(Bestowal of Rule)

4. Accipe regulam a sanctis patribus nobis
3. Domine, sancte pater, omnipotens eterne deus, adesto precibus, adesto votis, adesto famulationibus

\section{(Bestowal of Rule)}

(Bestowal of Rule)

3. VD eterne deus, adesto precibus nostris, adesto votis, adesto famulantibus

\section{Accipe regulam \\ 4. Accipe regulam} sancte conversationi sancte

conversationis

5. Domine deus omnipotens qui sororem moysi mariam

5. Domine deus omnipotens qui sororem moysi mariam

6. Famulam tuam quesumus domine tua semper gratia 
Table 4: Continued

\begin{tabular}{|c|c|c|c|c|c|}
\hline \multirow[b]{2}{*}{$\begin{array}{l}\text { Episcopal } \\
\text { Book }\end{array}$} & \multicolumn{2}{|c|}{ Ordines for the Consecration of an Abbot } & \multicolumn{3}{|c|}{ Ordines for the Consecration of an Abbess } \\
\hline & PRG & $\begin{array}{l}\text { Stage-Three Episcopal } \\
\text { Books }\end{array}$ & PRG & & $\begin{array}{l}\text { Stage-Three Episcopal } \\
\text { Books }\end{array}$ \\
\hline & & & $\begin{array}{l}\text { 5. Domine deus omnipo- } \\
\text { tens qui sororem } \\
\text { moysi mariam } \\
\text { 6. Concede quesumus } \\
\text { omnipotens Deus } \\
\text { famule tue abbatisse }\end{array}$ & (5) & \\
\hline & $\begin{array}{l}\text { 6. Omnium deus fons } \\
\text { bonorum } \\
\text { iustorumque }\end{array}$ & & $\begin{array}{l}\text { 7. Omnium domine fons } \\
\text { bonorum } \\
\text { iustorumque }\end{array}$ & $\begin{array}{l}\text { 7. Omnium domine fons } \\
\text { bonorum } \\
\text { iustorumque }\end{array}$ & \\
\hline & $\begin{array}{l}\text { 6b. Alia. Deus cui omnis } \\
\text { potestas et dignitas } \\
\text { famulatur }\end{array}$ & $\begin{array}{l}\text { 6. Deus cui omnis } \\
\text { potestas et dignitas } \\
\text { famulatur }\end{array}$ & $\begin{array}{l}\text { 8. Deus cui omnis potes- } \\
\text { tas et dignitas } \\
\text { famulatur }\end{array}$ & & \\
\hline & $\begin{array}{l}\text { 7. Deus eterne lucis } \\
\text { inventor, omnipoten- } \\
\text { tiam tuam } \\
\text { (Blessing specifically } \\
\text { for an abbess) }\end{array}$ & & & & \\
\hline & $\begin{array}{l}\text { 8. Domine deus omni- } \\
\text { potens qui sororem } \\
\text { moysi mariam }\end{array}$ & & & & \\
\hline
\end{tabular}


subject himself to the authority of the diocesan and the Roman church with a profession of obedience. ${ }^{107}$

Following the interrogation by the bishop, the abbot was to be clothed in "sacris vestibus," and then the litany, the Pater noster, and a series of Psalm verses with congregational responses were recited. ${ }^{108}$ The Gregorian prayer "Concede quesumus omnipotens Deus" was to be next, followed by the bestowal of the Rule and staff with their attendant prayers. The prayer read during the bestowal of the staff, "Accipe regulam a sanctis patribus nobis," is nearly identical to the related prayer found in the Claudius II Pontifical and in CCCC 44, but the explicit reference to Benedict as the Rule's author was replaced with a more general reference to the "holy fathers." 109 Similarly, "Accipe baculum pastoralis officii," the prayer recited during the bestowal of the staff, replicated the first half of the version of this prayer found in CCCC $44^{110}$ but did not include the second half, likely because this part appears as the prayer offered during the bestowal of the staff in the ordination rite for a bishop in stage-three episcopal books. ${ }^{111}$ Notably, the versions of the prayers for the Rule and staff are also found in episcopal books affiliated with the PRG, apparently indicating that they derive from this liturgical tradition. ${ }^{112}$

Unlike the ordo for the consecration of an abbot in stage-two episcopal books, the ordo in both the PRG and stage-three episcopal books does not include the bestowal of the ring. The removal of this sign of office from the rite may be owed to an increased desire among bishops to sharpen the distinction between a bishop's and an abbot's authorities through outward signs, like the insignia bestowed at their respective inductions into office. The bestowal of the ring, with its accompanying prayer, ${ }^{113}$ demonstrably signified a bishop's authority over his jurisdiction, particularly in matters pertaining to the binding and loosing of sins through the administration of penance. Over the course of the eleventh and twelfth centuries, the ring came to be numbered among the pontificalia that bishops alone could wear; the other insignia included the staff, sandals,

\footnotetext{
107 Ibid., 81-82.

108 Ibid., 82.

109 "Accipe regulam a sanctis patribus nobis traditam ad regendum et custodiendum gregem tibi a deo creditum quantum te deus ipse confortaverit ac fragilitas humana permiserit." Ibid.

110 "Accipe baculum pastoralis officii quem preferas caterve tibi commisse ad exemplum iuste severitatis et correctionis." Ibid.

111 "Accipe baculum pastoralis officii et sis in corrigendis vitiis pie seviens iudicium sine ira tenens cum iratus fueris misericordie reminiscens." Ibid., 77.

112 Le pontifical romano-germanique, 1:XXVI.9 and 12, respectively.

113 The prayer to be recited at the bestowal of the ring in the ordination rite for a bishop in stage-three episcopal books is the same prayer that appears in earlier sacramentaries and episcopal books: Pontifical of Magdalen College, 77. See n. 33 above.
} 
gloves, tunicle, dalmatic, and miter. Only abbots who received the papal privilege of wearing the ring and other pontificalia could also do so. This privilege often accompanied a monastery's exemption from the jurisdiction of its diocesan because, in wearing any of the pontificalia, an abbot would assume the visible appearance of a bishop, thereby communicating his independence from episcopal control. ${ }^{114}$ The privilege of wearing some or all of the pontificalia was one that was increasingly sought from the pope by English abbots after ca. $1050 .{ }^{115}$ The first abbot ever to be granted this privilege was Egelsin of St. Augustine's, Canterbury (1059-70), who was conceded the use of the miter and sandals by Pope Alexander II (1061-73) in 1063. ${ }^{116}$ In 1071, Baldwin of Bury St Edmunds (1065-97) was the next English abbot to be granted the use of any of the pontificalia, receiving the pastoral staff and ring. ${ }^{117}$ In 1157, Pope Adrian IV (1154-59) issued the bull Religiosam vitam to St. Albans, making Robert de Gorron (1151-66) the first English abbot permitted to wear all seven pontifical insignia. ${ }^{118}$ Such bids for exemption were fiercely contested by English bishops, who wished to keep monastic communities in their dioceses firmly under their jurisdiction. Thus, it would not be surprising if the liturgists behind stage-three episcopal books, most of which were produced at the scriptorium of the archbishop of Canterbury, adopted the PRG's ordo for the consecration of abbots because it omitted the bestowal of the ring. Some semblance of ecclesiastical hierarchy had to be maintained.

In the consecration rite, following the bestowal of the Rule and staff, the prayers "Cunctorum bonorum institutor deus qui per moysen" and "Eterne

114 Philipp Hofmeister, Mitra und Stab der wirklichen Prälaten ohne bischöflichen Charakter, Kirchengeschichtliche Abhandlungen 104 (Stuttgart, 1928; repr. Amsterdam, 1962).

115 David Knowles, The Monastic Order in England: A History of Its Development from the Times of St. Dunstan to the Fourth Lateran Council, 943-1216 (Cambridge, 1940; repr. 1950), 711; idem, "Essays in Monastic History, IV: The Growth of Exemption," Downside Review 50 (1932): 201-31, 396-436.

116 Philip Jaffé, ed., Regesta pontificum Romanorum, 2 vols. (Leipzig, 1885-88; repr. Graz, 1956), 1: no. 4541. See also the late fourteenth-century chronicle of the abbey by William Thorne, which likely drew on the thirteenth-century chronicle by Thomas Sprott but is no longer extant. Thorne's chronicle was edited by Roger Twysden in Historiae Anglicanae Scriptores Decem (London, 1652); see col. 1785. Knowles, Monastic Order, 711.

117 Thomas Arnold, ed., Memorials of St. Edmund's Abbey, 3 vols., Rolls Series 96 (London, 1890-96; repr. Wiesbaden, 1965), 1:344-46, esp. 345. The abbots of Bury did not receive the added privilege of wearing the miter until ca. 1182. This privilege is no longer extant, but Jocelin of Brakelonde's Chronica records the mitering of Abbot Samson (11821211) by Richard of Ilchester, bishop of Winchester (1173-88), on 28 February 1182 (ibid., 1:229-30). Knowles, Monastic Order, 711-12.

118 Walther Holtzmann, ed., Papsturkunden in England, 3 vols. (Göttingen, 1952), 3: no. 118. Knowles, Monastic Order, 711; Jane Sayers, "Papal Privileges for St. Albans Abbey and Its Dependencies," in The Study of Medieval Records: Essays in Honour of Kathleen Major, ed. D. A. Bullough and R. L. Storey (Oxford, 1971), 57-84; and Katie Bugyis, "Envisioning Episcopal Exemption: The Life of Christina of Markyate," Church History 84 (2015): 32-63. 
deus affluentem spiritum tue benedictionis super hunc famulum tuum" were to be recited. ${ }^{119}$ The versions of these prayers in stage-three episcopal books match those first seen in the Gellone and Phillips Sacramentaries and earlier AngloSaxon episcopal books, save CCCC 44. They also correspond with those found in the PRG's ordo. ${ }^{120}$ For the second prayer, the use of the earlier version meant that the Levite Stephen would still have served as the primary model of the abbatial office and that the abbot's governance and rule would have encompassed the "church" more broadly, not the "monastic flock" more narrowly. But different from earlier uses of this prayer, within the PRG's and stage-three episcopal books' ordo, it was to be recited in the manner of a preface to the canon of the mass, and the bishop was to lay his hands on the abbot when he read it.

The closing prayer to the ordo for the consecration of an abbot, "Deus cui omnis potestas et dignitas famulatur," is a brief petition, asking God to grant prosperity to the abbot's office. ${ }^{121}$ After the completion of this prayer, the mass was to continue in its proper order, resuming with the reading from the gospel.

The opening prayer to the ordo for the consecration of an abbess was to be "Exaudi domine preces nostras et super hanc famulam," the very prayer included in earlier sacramentaries and episcopal books as well as in the PRG's ordines for the ordination of a male and female deacon. ${ }^{122}$ This prayer also was to open the PRG's ordo for the consecration of a canonical abbess. ${ }^{123}$ Following this prayer, the bishop then was to recite "Omnipotentiam tuam domine humiliter imploramus," 124 a prayer yet to be seen in the versions of the consecration rite discussed thus far but found in the PRG's ordo for a canonical abbess. ${ }^{125}$ It asks for God to keep inviolate the "gift of blessing" and the "grace of consecration" that he bestowed on the abbess, "whom [he] deigned to raise up to holy order."

The next two prayers, "Eterne deus, adesto precibus nostris, adesto votis, adesto famulantibus" and "Accipe regulam sancte conversationis," are also unique to the PRG's ordo for a canonical abbess. ${ }^{126}$ The first was to be read in the manner of a preface; it recounts at length the virtues and duties envisioned

119 Pontifical of Magdalen College, 82-83.

120 Le pontifical romano-germanique, 1:XXVI.6 and 7.

121 "Deus cui omnis potestas et dignitas famulatur da famulo tuo prosperum sue dignitatis effectum in qua te semper timeat tibique iugiter placere contendat. Per." Pontifical of Magdalen College, 83.

${ }_{122}$ Ibid., 87. For the earlier discussion of this prayer, see $n .39$ above. See also Le pontifical romano-germanique, 1:XVI.13 (male deacon) and XXIV.7 (female deacon).

123 Ibid., 1:XXII.3.

124 "Omnipotentiam tuam domine humiliter imploramus ut super hanc famulam tuam $\mathrm{N}$. quam ad sacrum ordinem assumere dignatus es benedictionis tue donum dignanter infundas eique gratiam consecrationis tribuas ut quod percepit te protegente illesum custodiat. Per dominum. Per omnia secula seculorum. Amen." Pontifical of Magdalen College, 87.

125 Le pontifical romano-germanique, 1:XXII.4.

126 Ibid., 1:XXII.5 and 6, respectively. 
for an abbess's "service ... office ... ministry." 127 Significantly, and unlike any of the prayers in the ordo for an abbot, the bishop was to ask for the seven gifts of the Holy Spirit to rest upon the consecrand, as well as for "gravity of action and control of living that she may meditate on [God's] law day and night, keep [God's] commands, obey [God's] teachings, persevere in holy readings, despise earthly and transitory things, and be devoted to good works at all times." But also unlike the ordo for an abbot, this prayer emphasizes the sex of the consecrand both by praising the "examples of illustrious women" that adorn the church like "diverse flowers" and by identifying her as a "servant from the weaker sex." The second half of the prayer also commends the abbess's preservation of virginity so that she may be found worthy to join the heavenly wedding feast like the five wise virgins of the gospel parable who were rewarded for their vigilant watch for the bridegroom with oiled and trimmed lamps. ${ }^{128}$ Beyond a merely egoistic concern for her own sexual purity, the abbess had to lead "by the example of her chastity," presenting a "pure imitation to all who are subject to her."

A similar concern for purity is expressed in the prayer to be read during the bestowal of the Rule, "Accipe regulam sancte conversationis." 129 The Rule and

127 "VD. eterne deus. Adesto precibus nostris, adesto votis, adesto famulantibus, adesto consecrationibus qui omnia per verbum virtutis tue mirabiliter dispensas et dispensanda ministras, qui diversis floribus tuam semper exornas ecclesiam, dum eam et virtutum exemplis et illustrium feminarum irradias institutis, qui etiam de inferiori sexu hanc famulam tuam servitutis tue applicari dignatus es famulatui. Effunde super hanc famulam tuam N. quam in officium divinum fideliter dedicamus gratiam spiritus sancti ut tibi omni tempore eius servitus dignanter complaceat eamque dextera potentie tue benedicere et sanctificare digneris in opus ministerii tui condignum quatinus actum ministrationis sibi credite fideliter exequatur, et eiusdem sancti spiritus septiformis gratie virtute corroboretur. Requiescat ergo super eam precamur domine spiritus sapientie et intellectus, spiritus consilii et fortitudinis, spiritus scientie et pietatis, ac repleas eam spiritu timoris tui. Concede ei quoque gravitatem actuum censuramque vivendi ut in lege tua die ac nocte meditetur, mandata tua custodiat, dictis tuis obediat, sacris lectionibus insistat, terrena et transitoria despiciat, atque omni tempore bonis operibus inserviat, omnem libidinem prave voluptatis superet, amorem honeste castitatis teneat ut tibi sponso venienti cum lampadibus suis inextinguibilibus possit occurrere et precedentium virginum choro iungi et ne cum stultis excludatur regalem ianuam cum sapientibus virginibus licenter introeat. Abundet in ea totius forma virtutis, auctoritas modesta, pudor constans, innocentie puritas, et spiritualis observantia discipline. In moribus eius precepta tua fulgeant ut sue castitatis exemplo cunctis sibi subditis imitationem prebeat puram et bonum conscientie testimonium ostendens in christo ihesu firma et stabilis perseveret, atque ita preceptum ministerium te auxiliante peragat, quatinus ad eternam remunerationem te donante pervenire mereatur. Per." Pontifical of Magdalen College, 88.

128 Cf. Matt. 25:1-13.

129 "Accipe regulam sancte conversationis simulque gratiam divine benedictionis et ut per hanc cum grege tibi credito in districti die iudicii domino incontaminata representari valeas ipse te adiuvare dignetur qui cum deo patre in unitate spiritus sancti." Pontifical of Magdalen College, 88. 
God's grace are offered as the means by which the abbess would be able to lead the flock entrusted to her care to salvation. She must strive to present herself and her fellow sisters "untainted" to God.

The final two prayers, "Domine deus omnipotens qui sororem moysi mariam" and "Famulam tuam N. quesumus domine tua semper gratia," often appear in stage-three English episcopal books as a combined prayer. The latter prayer is a short blessing, asking God to bestow his grace on the abbess and to lead her to eternal life without fault. ${ }^{130}$ The former prayer was seen earlier in the Gellone and Phillipps Sacramentaries, but not in any of the Anglo-Saxon episcopal books. ${ }^{131}$ It is also found in the PRG's ordines for a monastic and canonical abbess, though there is a slight difference between the versions of the prayer in these two ordines: the monastic abbess is exhorted to uphold the "monastica norma," the canonical abbess the "canonica norma."132 The version of the prayer found in stage-three English episcopal books is nearly identical with the one in the PRG's ordo for a canonical abbess, except Miriam now accompanies a group of virgines, instead of mulieres, through the waves of the Red Sea. ${ }^{133}$ Recharacterized in this way, Miriam's band of singers and musicians also would have exemplified the ideal of sexual purity for a community of women religious and inspired the abbess, as a new Miriam, to take responsibility for preserving her sisters' integrity.

The Rule was the only sign of the abbatial office that was to be bestowed on the abbess during her consecration. Like the abbot, she was not to receive the ring, but she also was not to receive the staff. Episcopal books related to the PRG tradition seem to have introduced this distinction in the distribution of abbatial insignia. The reasons why an abbess was not to be given the ring were probably the same as those articulated above for an abbot, but the reasons for why she was not to be given the staff are less apparent. Arguably, if the bestowal of the staff made abbesses appear too much like bishops, then abbots also would have been divested of this sign. More likely, the bestowal of the staff made abbesses appear too much like abbots, for the staff served as an effective, visible reminder that the heads of monasteries, regardless of their gender, possessed the same temporal and spiritual authority. Without the staff, as Felice Lifshitz has pointedly noted, an abbess was "a castrated father, or at least a deformed one" 134 ; her authority was rendered impotent, or at least less potent than an abbot's. And

130 "Famulam tuam N. quesumus domine tua semper gratia benedicat et inculpabilem ad vitam perducat eternam." Ibid., 89.

131 For this prayer, see n. 17 above.

132 Le pontifical romano-germanique, 1:XXXII.10 and XX.7, respectively.

133 Pontifical of Magdalen College, 88-89.

134 Liftshitz, "Is Mother Superior? Towards a History of Feminine Amtcharisma," in Medieval Mothering, ed. John Carmi Parsons and Bonnie Wheeler (New York, 1996), 11738 , at 131 . 
without the staff and ring, an abbess was clearly distinguished from and subordinated to her immediate spiritual father: the bishop who consecrated her. Within the context of the PRG's ordo for a canonical abbess and the ordo for an abbess found in stage-three episcopal books, this "castration" would have been imperceptible given the prayers' thorough feminization of an abbess's authority. It only would have been detectable in the PRG's ordo for a monastic abbess, given its preservation of many of the prayers found in the ordo for an abbot. These prayers call an abbess, like an abbot, to imitate the patriarch Moses, the faithful servants in the parable of the talents, and the Levite Stephen, as well as Miriam, thereby gendering her authority both masculine and feminine. But this ordo did not have an enduring impact on the production of medieval English episcopal books; its sister ordo did, thus effacing any residual vestige of the consecration rite that abbesses once shared with abbots.

\section{Self-Fashioning Female Abbatial Authority}

As irrevocable as the effect of the PRG's ordines seems to have been on how the English church ritually delineated an abbess's spiritual authority and distinguished it from an abbot's from at least the late eleventh century through the twelfth, the normative ideal commended in the consecration ordo was anything but determinative of how abbesses carried out their office in actual practice during this period. Even with respect to the insignia that they claimed for their office, abbesses often exceeded what was liturgically prescribed. The material remains from several communities of women religious demonstrate that abbesses continued to wield the pastoral staff in the public image that they projected through their communities' seals, monumental sculptures, and burial goods.

Conventual seals and personal seals of abbesses from Barking, Elstow, Romsey, and Shaftesbury Abbeys, which variously date from the twelfth to the thirteenth centuries, all represent the abbesses figured on them with pastoral staffs in hand. The thirteenth-century conventual seal of Barking features the abbey's early Anglo-Saxon founders, Earconwald (d. 693) and Ethelburh (fl. 664), as well as Ethelburh's successor, Hildelith (fl. ca. 700), under three sculpted arches; all carry pastoral staffs (Fig. 1). ${ }^{135}$ At the base of the seal, under a rounded arch, a veiled abbess appears in half-length; she too holds a staff. On the counterseal, a veiled abbess stands on a footboard with a staff in her right hand and a book, possibly the Benedictine Rule, in her left hand. ${ }^{136}$ The legend gives additional character to the abbess by casting her in a Pauline mold: "GRACIA DEI SVM ID QVOD SVM" (1 Cor. 15:10). The personal seal of Matilda (d. by 1202), abbess

135 London, BL, Seal LXII.97; Walter de Gray Birch, Catalogue of Seals in the Department of Manuscripts in the British Library, 6 vols. (London, 1887-1900), 1: no. 2588.

136 London, BL, Seal LXII.98; Catalogue of Seals, 1: no. 2589. 


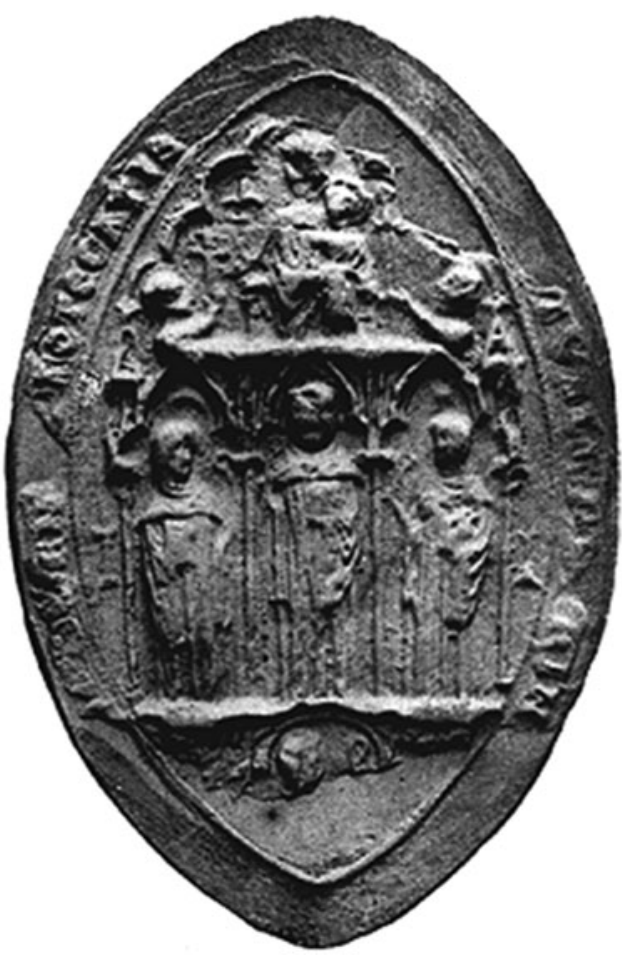

Figure 1: London, BL, Seal LXII.97, Barking Abbey's thirteenth-century conventual seal. (C) The British Library Board.

of Barking and daughter of King Henry II (1154-1189), which is still affixed to an early thirteenth-century charter, also features the abbess with a staff in her left hand and a book in her right hand. ${ }^{137}$

The conventual seals of Elstow and Shaftesbury Abbeys are very similar to Barking's in their placement of a veiled abbess with a pastoral staff in hand beneath the patron saint(s) of her community. The thirteenth-century seal of Elstow's chapter places an abbess kneeling in prayer, both hands clasped around her staff, beside two of her community members, below the abbey's patron saints, the Virgin Mary and St. Helena. ${ }^{138}$ On the reverse of the thirteenth-century conventual seal of Shaftesbury, a veiled abbess is figured in half

137 London, BL, Add. Ch 15584; Catalogue of Seals, 1: no. 2591.

138 London, BL, Seal LVIII.34; Catalogue of Seals, 1: no. 3105. The matrix that impressed this seal continued to be used at Barking until its dissolution in 1539. See PRO E322/83; R. H. Ellis, Catalogue of Seals in the PRO, vol. 1, Monastic Seals (London, 1986), M311. 
length at prayer with both hands around her staff at the base of the seal, beneath Christ's coronation of the Virgin Mary. ${ }^{139}$

The twelfth-century conventual seal of Romsey seems to feature the abbey's first abbess and one of its patron saints, Ethelfleda (d. 959), the daughter of King Edward the Elder (899-924), in full-length frontal view, holding a staff in her right hand and a book in her left hand. ${ }^{140}$ Additional material evidence from Romsey attests to its abbesses' possession of the pastoral staff. Part of a thirteenth-century sepulchral slab, which likely once covered an abbess's tomb, is still preserved in the north aisle of Romsey's twelfth-century Norman church; it simply depicts in relief a robed arm extended, holding a staff. ${ }^{141}$

At Nunnaminster, among the thirteenth-century burials in the abbey's church, are the remains of a wooden staff with a carved ivory top. It was buried with a woman, who was over forty-five years old at the time of her death, in a stone coffin located in the south aisle of the church. The construction of an enclosed chapel around the coffin indicates the significance of this woman to the Nunnaminster community: she likely was an abbess or a prominent lay official. ${ }^{142}$

\section{Conclusion}

Medieval liturgical ordines, like any of the other normative texts produced and promulgated within the Western church, whether penitentials or conciliar decrees, attempted to articulate and effect an ideal vision for the Church and its mission in the world. Rites of initiation, ordination, consecration, and blessing are especially revealing of how some liturgists envisioned leaders and members carrying out their individual and corporate vocations for the Church's continued edification and salvation. Even those vowed to the monastic conversatio, who were governed by the particular rules and customs of their communities, were to be indelibly formed by the rituals that marked their entrance into religious life and their promotion within it. Abbots and abbesses, those specially charged with ensuring the spiritual and material well-being of their communities, officially received their pastoral burdens at their elections, but their consecrations limned the rite of

139 London, BL, Seal LXII.50; Catalogue of Seals, 1: no. 4004. This matrix continued to be used at Shaftesbury until its dissolution in 1539. See PRO E322/211; Catalogue of Seals in the PRO, M769.

140 London, BL, Seal LXIV.1; Catalogue of Seals, 1: no. 3927. For another twelfthcentury impression of this matrix, see PRO E326/11100; Catalogue of Seals in the PRO, M735. Ellis dates this seal to ca. 1130. See also Diana Coldicott, Hampshire Nunneries (Chichester, 1989), 72.

141 Nikolaus Pevsner and David Lloyd, Hampshire and the Isle of Wight (Baltimore, 1967), 486; Roberta Gilchrist, Gender and Material Culture: The Archaeology of Religious Women (New York, 1994), 19.

142 Coldicott, Hampshire Nunneries, 98; Gilchrist, Gender and Material Culture, 59. 
passage from member to leader and dramatically communicated through prayer, sign, chant, and gesture the qualities, roles, and responsibilities incumbent on their office.

The development of the consecration rite for abbesses and abbots has a complex history. Over the course of the early and central Middle Ages, the innovations of different liturgists transformed this rite from a simple collection of prayers into a complex ordo that was initially shared across gender lines but ultimately divided by them. English episcopal books produced from 900 to 1200 provide an illustrative test case for tracing this development. From roughly the beginning of the tenth century until the middle of the eleventh, abbots and abbesses were consecrated according to the same rite, from the prayers recited to the insignia of office bestowed. There was no distinction based on gender between the temporal and spiritual authorities ritually conferred upon the consecrand. But in the second half of the eleventh century, with the introduction of the ordines from the PRG tradition into English episcopal books, the consecration rite once shared by abbots and abbesses split along gender lines into two distinct ordines with different conceptions of abbatial authority. The authority of abbots remained essentially intact, preserving many of the powers received in earlier episcopal books, save those that encroached upon bishops' jurisdiction. Abbesses, however, were cast into a form of abbatial leadership that was nearly thoroughly feminized and bore little resemblance to the one that they once shared with abbots. The loss of the pastoral staff demonstrated most concretely the diminishment of abbesses' authority. But as with all normative texts, the consecration ordo for abbesses that came to dominate English episcopal books during the central Middle Ages was limited in its effect on how abbesses actually perceived and performed their office. The material remains from several female monastic communities reveal that some abbesses continued to wield their staffs just as impressively as their male counterparts did.

Saint Martin's University

Keywords: consecration, abbot, abbess, bishop, and liturgy 